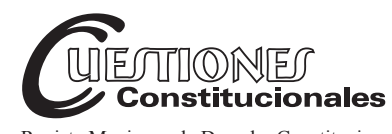

Revista Mexicana de Derecho Constitucional Núm. 43, julio-diciembre 2020

\title{
El precedente judicial en México. Fundamento constitucional y problemas básicos
}

\author{
Judicial precedent in Mexico. Constitutional \\ basis and basic problems
}

\section{Rubén SÁNCHEZ GIL*}

RESUMEN: Aunque el precedente judicial ha sido una figura con creciente importancia en México durante las últimas décadas - sobre todo en materia constitucional一, persiste una concepción tradicional a su respecto. Pero en años recientes, una posición más apegada a la tradición angloamericana se ha introducido en la jurisprudencia mexicana. Trayendo al sistema jurídico mexicano elementos de la teoría del precedente de aquella cultura jurídica, este estudio se pregunta por las bases constitucionales del precedente judicial en México, y echa nueva luz sobre sus dos problemas fundamentales: el uso de "tesis" y el efecto vinculante de los criterios judiciales. Contribuye así a una reanimada apreciación del papel jurídico y político de la judicatura en México, que daría nuevo valor al derecho que elaboran los jueces en este país.

Palabras clave: jurisprudencia, precedente, México, judicatura, aplicación judicial del derecho, efecto vinculante.
ABSTRACT: Though judicial precedent has been a figure with growing importance in Mexico during past decades-specially regarding constitutional law-, a traditional conception towards it persists. But in recent years, a closer to the Anglo-American tradition stance found its way into Mexican caselaw. Bringing elements from the said legal culture to Mexican law, this study asks for the constitutional grounds of judicial precedent in Mexico, and sheds new light upon its two main problems: the use of "thesis" and the binding effect of judicial holdings. Thus, it contributes to a fresh appraisal of the Mexican bench's legal and political role that would give new value to judge-made law in this country.

Keywords: caselaw, case law, precedent, mexico, judicial branch, adjudication, binding effect.

* Doctor en Derecho por la UNAM. Profesor en la Facultad de Derecho de la Universidad Autónoma de Yucatán. Investigador nacional, nivel I, del Sistema Nacional de Investigadores. México. ORCID: 0000-0002-2094-0855 Correo electrónico: ruben. sanchez@correo.uady.mx. 


\author{
SUMARIO: I. Introducción. II. El precedente judicial. III. El \\ sistema jurisprudencial federal en México. IV. Dos problemas \\ mexicanos. V. Reflexiones finales.
}

\title{
I. INTRODUCCIÓN
}

La cultura gestada con base en el derecho romano, de la cual abreva el sistema jurídico mexicano, tradicionalmente se ha pronunciado a favor de la preeminencia de la ley y de un papel limitado de la función jurisdiccional. ${ }^{1}$ El apotegma con el cual Montesquieu señaló que al juez es solamente la "boca de la ley"' ha sido un pilar fundamental de nuestra concepción jurídica.

Sin embargo, gracias al constitucionalismo y al derecho internacional de los derechos humanos, en las últimas décadas se ha transformado la visión de la tradición romanista sobre la función de los jueces y de la importancia de su labor. ${ }^{3}$ Van de la mano el reconocimiento a la labor creativa de la interpretación judicial ${ }^{4}$ y la creciente relevancia (jurídica y política) que la jurisprudencia ha adquirido en países de tradición neorromanista. ${ }^{5}$

Esta misma situación se ha desarrollado en México. Por muchos años la jurisprudencia ha sido en nuestro país, en el mejor de los casos, un elemento meramente auxiliar de la enseñanza y de la práctica jurídicas. Un conjunto de factores propiciaron esa situación: el peso de la tradición

\footnotetext{
1 Merryman, John Henry y Pérez-Perdomo, Rogelio, The Civil Law Tradition. An Introduction to the Legal Systems of Europe and Latin America, 3a. ed., Stanford, Stanford University Press, 2007, pp. 34 y ss.

2 "Pero los jueces de la nación, como es sabido, no son más ni menos que la boca que pronuncia las palabras de la ley, seres inanimados que no pueden mitigar la fuerza y el rigor de la ley misma", Montesquieu, Carlos Luis de Secondat, barón de la Brède y, Del espiritu de las leyes, 13a. ed., trad. de Nicolás Estévanez, México, Porrúa, 2000, lib. XI, cap. VI, p. 108 (cursivas añadidas).

3 Merryman y Pérez-Perdomo, op. cit., nota 1, pp. 37 y 38.

4 Zambrano, Pilar, La inevitable creatividad en la interpretación jurídica. Una aproximación iusfilosófica a la tesis de la discrecionalidad, México, UNAM, Instituto de Investigaciones Jurídicas, 2009, pp. 64 y 78.

5 MacCormick, D. Neil y Summers, Robert S., "Reflexiones generales adicionales y conclusiones", en idem (eds.), La interpretación del precedente. Un estudio comparativo, México, TEPJF, 2016, p. 495 (refiriendo el precedente judicial como "un nuevo tipo de autoridad legal aceptada en los países del derecho civil", que resulta "esencial para la constitución de un caso [jurídicamente] satisfactorio").
} 
neorromanista; una dogmática constitucional que, de modo conveniente para el sistema político, menospreció la labor de los tribunales; ${ }^{6}$ y muy particularmente la insuficiente difusión —en especial en las entidades federativas - del Semanario Judicial de la Federación, que persistió por décadas. ${ }^{7}$ En los últimos lustros, estos factores se han superado gracias al papel relevante que han adquirido la Suprema Corte de Justicia de la Nación y otros tribunales en nuestra transición democrática, y a una más eficiente difusión de la jurisprudencia en nuestro país debida a los esfuerzos informáticos - y económicos — del Poder Judicial de la Federación.

Sin embargo, a grandes rasgos, la creciente importancia de la jurisprudencia en México no ha ido acompañada de un esfuerzo similar por comprender a cabalidad el precedente judicial como fuente jurídica. Muchos problemas que tenemos en la práctica se deben al desconocimiento - por parte de tribunales y de postulantes - de las numerosas implicaciones del empleo del precedente en la argumentación jurídica.

El papel del derecho que los jueces elaboran (judge-made law) va más allá de la obligación de aplicar, bajo determinadas condiciones, las soluciones ideadas por los tribunales para casos previos. El precedente judicial es una figura con muchos más "matices y complicaciones" de los que comúnmente creemos, y se requiere "paciencia y agudeza para superarlos". 8

En los últimos años, los tribunales mexicanos han advertido esta situación y volteado a una teoría del precedente judicial, de obvia confección anglosajona, para subsanar las deficiencias conceptuales de nuestro sistema jurisprudencial, y explicarlo y operarlo con mayor claridad. ${ }^{9}$ Por su parte, sin perjuicio de algunos esfuerzos anteriores que resultaron aislados, muy recientemente la doctrina mexicana ha generado un par de obras que vislumbro como cruciales para ver en este país con diferentes ojos el de-

6 Cossío Díaz, José Ramón, Dogmática constitucional y régimen autoritario, 2a. ed., México, Fontamara, 2000, pp. 68 y 69.

7 Zertuche García, Héctor Gerardo, La jurisprudencia en el sistema jurídico mexicano, 2a. ed., México, Porrúa, 1992, pp. 355 y 356.

8 Garner, Bryan A. et al., The Law of Judicial Precedent, St. Paul, Thomson Reuters, 2016, p. 1 (cursivas añadidas).

9 Aparte de ejemplos señalados abajo, véase Primera Sala, amparo directo 49/2013, sentencia del 19 de noviembre de 2014, con. IV, pp. 29 y 30 (que habla de una "teoría del precedente" y expone la diferencia entre el precedente vinculante y el persuasivo, para concluir que "las tesis aisladas son precedentes no obligatorios"). 
recho de confección judicial, obras que, para comenzar, ya no aluden a la "jurisprudencia", sino al "precedente", cambio terminológico aparentemente inocuo, pero que en realidad parece anunciar un enfoque diferente al que tradicionalmente ha prevalecido en México. ${ }^{10}$

Este trabajo pretende contribuir a la nueva perspectiva sobre la jurisprudencia que se intenta propagar en México. Obviamente, es imposible siquiera presentar aquí un catálogo de todos los problemas que suscita el precedente judicial, tanto de modo general como en particular para nuestro sistema jurídico. En tal virtud, luego de exponer conceptos generales sobre el precedente judicial - primordialmente basados en la tradición del common law-, y apuntar referencias elementales del sistema jurisprudencial de nuestro país, esbozaré tres cuestiones básicas para repensar la concepción jurisprudencial mexicana.

Dichas cuestiones son: 1) el fundamento constitucional del precedente judicial; 2) la relación entre las "ejecutorias" que contienen el precedente y las "tesis" que lo divulgan — tan características de nuestro sistema-, y 3 ) la matizada diversidad de grados de efecto vinculante de los precedentes, muy lejana de la proverbial dicotomía vinculante/orientador imperante en nuestra práctica jurídica. La primera de estas cuestiones no sólo tiene una importancia normativa, sino que también es ineludible para aproximarnos al precedente judicial: determinar los valores constitucionales a que sirve esta figura y sus implicaciones proporciona una visión distinta a la formal y mecánica que ha prevalecido en nuestro país. Las dos restantes, a mi parecer, son los principales problemas prácticos que enfrenta la comprensión del precedente judicial en México.

Reflexionar sobre estos tópicos es imperativo para perfeccionar la aplicación del derecho en nuestro país. La complejidad actual de nuestro sistema jurisprudencial, tanto por la pluralidad de órganos que pueden sentar precedentes como por la variedad de relaciones jurídicas con que se relacionan, exigen una visión actualizada del precedente judicial. Ojalá que este trabajo pueda ser punto de partida para una más amplia discusión sobre el tema, que corresponderá efectuar a toda la comunidad jurídica mexicana.

10 Gómora Juárez, Sandra, Un análisis conceptual del precedente judicial, México, UNAM, Instituto de Investigaciones Jurídicas, 2018, y Bernal Pulido, Carlos et al. (coords.), El precedente en la Suprema Corte de Justicia de la Nación, México, SCJN, Centro de Estudios Constitucionales, 2018. 


\section{EL PRECEDENTE JUDICIAL}

\section{Precisiones conceptuales}

Debido a la "anarquía conceptual"11 en esta materia, es necesario definir los conceptos fundamentales del presente estudio. Una nomenclatura precisa y concreta en torno a los diversos conceptos jurisprudenciales ayudaría en México a superar muchos malentendidos.

Por lo general, y a grandes rasgos, jurídicamente se tiene por "precedente" al criterio jurídico empleado en una resolución judicial que, en términos que adelante precisaré, ${ }^{12}$ debe servir como base para decidir casos futuros referentes a tópicos o hechos similares. ${ }^{13}$ Es posible que el término "precedente" también pueda aplicarse a criterios sentados en ámbitos diferentes de los estrictamente jurisdiccionales, ${ }^{14}$ pero su empleo en tal sentido es muy reducido, por lo que esta acepción resulta prácticamente insignificante.

Por su parte, el término "jurisprudencia” se emplea para designar: 1) el "[c]onjunto de las sentencias de los tribunales, y [de la] doctrina que contienen"; 2) el "[c]riterio sobre un problema jurídico establecido por una pluralidad de sentencias concordes", y 3 ) en un sentido ahora desusado, a la "[c]iencia del derecho". ${ }^{15}$

En los países de tradición neorromanista, como México, cobra especial relevancia el segundo de los anteriores significados. Parece que la desconfianza de los sistemas de nuestra cultura jurídica hacia los juzgadores

\footnotetext{
11 Zertuche García, op. cit., nota 7, p. 86.

12 Infra, § IV.2.

13 Garner et al., op. cit., nota 8, p. 22.
}

14 Gerhardt, Michael J., The Power of Precedent, Nueva York, Oxford University Press, 2011, p. 3 (que integran en un amplio concepto las resoluciones judiciales y las de órganos de distinta naturaleza, y aun prácticas históricas y tradiciones). Hablando de "cierto valor vinculante" del "precedente administrativo", apoyado por jurisprudencia ordinaria, constitucional y comunitaria, y basado en los principios de igualdad, de buena fe y de confianza legítima. Véase García de Enterría, Eduardo y Fernández, Tomás-Ramón, Curso de derecho administrativo I, 10a. ed., Madrid, Civitas, 2000, pp. 76 y 77, y también la obra de Silvia Díez referida infra, nota 61.

15 Real Academia Española, Diccionario de la lengua española, 23a. ed., Madrid, 2014, disponible en: http://dle.rae.es, s. v. "jurisprudencia" (2 de octubre de 2017). Cfr. Muñoz Machado, Santiago (dir.), Diccionario del español jurídico, Madrid, RAE-Consejo General del Poder Judicial, 2016, disponible en: http://dej.rae.es, s. v. "jurisprudencia” (idem). 
llevó a negar cualquier efecto vinculante a sus precedentes "aislados", por lo que les niega la calidad de "jurisprudencia”, y exige su reiteración para que la persistencia del criterio judicial sea signo de su corrección. ${ }^{16}$ Pero en el contexto mexicano es usual emplear el término "jurisprudencia" en la primera de las acepciones relacionadas en el párrafo anterior; es decir, en el sentido de "conjunto de decisiones y criterios judiciales" antes señalado; este concepto equivale al concepto de case law anglosajón, ${ }^{17} \mathrm{o}$, en otras palabras, al conjunto de normas jurídicas que resultan de las decisiones judiciales.

En el último sentido usaré en este trabajo el término "jurisprudencia"; con él aludiré como conjunto a las resoluciones, los criterios o los precedentes judiciales, sin reparar en si son de aplicación (absolutamente) imperativa por algún motivo, en particular por su carácter reiterado. En cambio, especificaré con el calificativo "vinculante" o similares cuando me refiera a esta última especie de precedentes.

\section{El precedente en el common law}

Es muy sabido que el uso obligatorio del precedente judicial como elemento de decisión jurídica es el aspecto más característico de la tradición jurídica anglosajona o common law. ${ }^{18}$ Una mirada a la historia de la evolución de esta práctica perfila el trasfondo en que opera el precedente en esta cultura y sus implicaciones.

16 En particular, para México, véase Vallarta, Ignacio L., El juicio de amparo y el writ of habeas corpus. Ensayo crítico-comparativo sobre esos recursos constitucionales, México, Imprenta de Fco. Díaz de León, 1881 (4a. ed. facsimilar, Obras, México, Porrúa, 1989, t. V), pp. 316-322. Para España, véase Ferreres Comella, Víctor, "Sobre la posible fuerza vinculante de la jurisprudencia”, en idem y Xiol Ríos, Juan Antonio, El carácter vinculante de la jurisprudencia, México, Fundación Coloquio Jurídico Europeo-Fontamara, 2010, pp. 104 y 105 (habla del mínimo de dos resoluciones del Tribunal Supremo para que haya "jurisprudencia"); pero en relación con el Tribunal Constitucional, $c f r$. artículo 164.1 de la Constitución de ese país. En Alemania abundan las referencias a la "jurisprudencia constante" (ständige Rechtsprechung), como se califica a los criterios judiciales que han alcanzado un alto grado de reiteración. Véase también Garvey Algero, Mary, "The Sources of Law and the Value of Precedent: A Comparative and Empirical Study of a Civil Law State in a Common Law Nation", Louisiana Law Review, Nueva Orleans, Universidad Loyola, vol. 65, 2005, disponible en: http://bit. ly/2yUmVn4, pp. 787 y ss.

17 Garner et al., op. cit., nota 8, p. 787.

18 Patterson, Edwin W., Jurisprudence: Men and Ideas of the Law, 1953, p. 300, citado por ibidem, p. 16. 
Los primeros tribunales que estableció el rey normando Guillermo el Conquistador resolvían los conflictos sometidos a su decisión con base en las diversas reglas que seguían los pobladores anglosajones, daneses y normandos de la actual Inglaterra. Sin embargo, dichos tribunales elaboraron nuevas normas cuya aplicación se fue extendiendo por todo el reino sustituyendo a las antiguas, formándose así un derecho "general" o "común" a todos los súbditos ingleses. ${ }^{19}$

Por eso, la expresión common law designa al conjunto de decisiones judiciales que contenían esas nuevas normas, y por extensión la jurisprudencia en general de manera sinónima a la locución case law. Pero ella también denomina la tradición jurídica a que dio lugar el sistema jurídico inglés, integrado al comienzo por reglas "no escritas", consuetudinarias, a diferencia del derecho legislado de nuestra tradición, pues los antiguos jueces ingleses —y algunos continúan haciéndolo- sólo anunciaban su decisión sin registrarla por escrito. ${ }^{20}$

Los principios que actualmente rigen la aplicación de la jurisprudencia en los sistemas de common law resultaron de una muy larga evolución. La reiteración de las soluciones a casos previos fue una costumbre de los antiguos tribunales ingleses, y muy probablemente la originó un motivo tan propio del pragmatismo que caracteriza a esta cultura jurídica: aplicar la respuesta que se dio al caso anterior era lo más sencillo, pues " $[\mathrm{n}] \mathrm{o}$ había necesidad de considerar una cuestión de novo si se había decidido recientemente", ${ }^{21}$ lo que quizá se deba al instinto imitativo humano y al "profundamente arraigado sentido de justicia (fairness) y regularidad de la psique humana". ${ }^{22}$ A diferencia de lo que sucede actualmente, a comienzos del siglo XIV, "los casos se usaban sólo como prueba de una costumbre (custom) del tribunal", y de un modo similar al de la tradición romanista, un caso aislado no tenía efecto vinculante, pero "una costumbre bien establecida (probada mediante la invocación más o menos casual de casos) se veía sin duda como fuertemente persuasiva". ${ }^{23}$ Entre los siglos XVI y

19 Rabasa, Óscar, El derecho angloamericano. Estudio expositivo y comparado del “common law", 2a. ed., México, Porrúa, 1982, pp. 67 y 68.

20 Ibidem, pp. 25-26, y Garner et al., op. cit., nota 8, pp. 1 y 789.

21 Plucknett, Theodore Frank Thomas, A Concise History of the Common Law, 5a. ed., Boston, Little, Brown and Co., 1956 (facsímil, Indianápolis, Liberty Fund, 2010), disponible en: http://bit.ly/lGhaheh, p. 342.

22 Garner et al., op. cit., nota 8, pp. 15 y 16.

23 Plucknett, op. cit., nota 21, p. 347. 
XVII se estableció el principio de que un solo precedente podía ser vinculante, pero tal autoridad se concedió únicamente a las decisiones del Tribunal de la Cámara del Tesoro (Court of Exchequer Chamber). ${ }^{24}$

Durante el siglo XVII aún se citaban numerosos casos para demostrar la existencia de una práctica judicial que sirviera de base a una decisión; esto, a diferencia de lo que ocurre en los sistemas desarrollados de precedentes, en los cuales "un caso es tan bueno como una docena si cubre claramente el punto", y en ellos "consecuentemente las citas [de casos] son pocas y puntuales", ${ }^{25}$ lo que precisamente constituye la regla en la tradición anglosajona, en la cual el efecto vinculante del precedente es categórico. ${ }^{26}$ Gracias a diversos cambios institucionales, hasta el siglo XIX se sentaron las bases para consolidar el sistema de precedentes: la exclusión de jueces legos y la profesionalización de la judicatura; la organización de un solo tribunal de apelaciones en lugar de varios, y, last but not least, la estandarización y el carácter semioficial de los reportes de casos. ${ }^{27}$

Estas condiciones permitieron que en Inglaterra $-\mathrm{y}$ por su influencia, en los Estados Unidos ${ }^{28}$ - se consagrara el principio stare decisis,${ }^{29}$ que ordena deferencia a los precedentes judiciales, y que el common law desarrollara técnicas muy elaboradas para manejar los precedentes, que son un aspecto básico de su metodología. ${ }^{30}$ La Suprema Corte norteamericana explicó así la trascendencia de dicho principio:

\footnotetext{
24 Ibidem, p. 348.

25 Ibidem, p. 349.
}

26 Ferreres Comella, op. cit., nota 16, p. 69.

27 Plucknett, op. cit., nota 21, p. 350. Véase también Laporta, Francisco J., "La fuerza vinculante de la jurisprudencia y la lógica del precedente", en Ferreres Comella y Xiol Ríos, op. cit., nota 16, pp. 35 y 36.

28 Rabasa, op. cit., nota 19, pp. 123-126 (expresan diversas precisiones sobre la recepción del derecho inglés en los Estados Unidos).

29 Garner et al., op. cit., nota 8, p. 5. La expresión es una reducción de la frase "stare decisis et non quieta movere" (estarse o atenerse a lo decidido y no mover lo establecido); refiere completa esta locución, véase Townsend v. Jemison, 50 U.S. (9 Howard) 407, 414 (1850). La indicada regla tiene un origen medieval, y se dice que éste es "continental y no anglosajón" (Laporta, op. cit., nota 27, p. 35); cfr. McKean, Jr., Frederick G., "The Rule of Precedents", University of Pennsylvania Law Review, Filadelfia, vol. 76, núm. 5, marzo de 1928, disponible en: http://bit.ly/2fKYC6j, p. 481 (dice que el origen de este principio es "nebuloso" $[$ hazy]).

30 López Medina, Diego Eduardo, El derecho de los jueces, 2a. ed., Bogotá, LegisUniversidad de los Andes, 2009, pp. 231 y 232. 
[Esta] Corte ha reconocido frecuentemente la "fundamental importancia" del stare decisis, el principio jurídico básico que ordena el respeto judicial a las decisiones previas de un tribunal y a las reglas jurídicas que comprenden.... ha apuntado que... "promueve el imparcial, predecible y consistente desarrollo de los principios jurídicos, fomenta la confianza en las decisiones judiciales, y contribuye a la efectiva y percibida integridad del proceso judicial"... El stare decisis evita con ello la inestabilidad y la injusticia (unfairness) que acompañan la interrupción de las expectativas jurídicas establecidas. Por esta razón, el imperio del derecho (rule of law) demanda que adherirnos a nuestra jurisprudencia (case law) previa sea la regla. Apartarse del precedente es excepcional, y requiere "justificación especial". ... Esto es particularmente cierto donde, como aquí, el principio se ha establecido mediante iteración y reiteración (iteration and reiteration) por un largo periodo de tiempo. ${ }^{31}$

\section{3. ¿Hay una "teoría general” del precedente judicial?}

La primera objeción que surge en países romanistas como México contra el precedente judicial es que se trata de una figura ajena a nuestra tradición jurídica, pues corresponde al common law, cuyos jueces siempre han tenido un papel creativo y protagónico, a diferencia del limitado que se ha atribuido a los nuestros. ${ }^{32}$ Pero esta dificultad no es insuperable.

Resulta claro que "el precedente es ahora una parte significativa en la toma de decisiones legales y en el desarrollo del Derecho en [muchos] países y tradiciones legales". ${ }^{33}$ La decisión de los casos particulares siguiendo la respuesta dada a sus similares, o sea, la regla stare decisis, es "un principio común a cualquier sistema jurídico", aunque haya diferencias más o menos significativas entre los diversos ordenamientos —en particular respecto de la intensidad de la vinculación a los precedentes-, pero que finalmente pueden ser contingentes. ${ }^{34}$

\footnotetext{
31 Randall v. Sorrell, 548 U.S. 230, 243-244 (2006).

32 Ferreres Comella, op. cit., nota 16, pp. 47 y 48.

33 MacCormick y Summers, op. cit., nota 5, p. 493. Véase también Alexy, Robert,
} Theorie der juristischen Argumentation. Die Theorie des rationalen Diskurses als Theorie der juristischen Begründung, 4a. ed., Fráncfort del Meno, Suhrkamp, 2001, pp. 334335 (señala el papel del precedente [Präjudiz] como un "aspecto esencial" de la argumentación jurídica, y que su "importancia fáctica ... aun en el derecho continental-europeo... es hoy por todas partes resaltada" [cursivas en el original]).

34 MacCormick y Summers, op. cit., nota 5, pp. 497-507, y Orozco Muñoz, Mar- 
Al cabo, diferencias de algún tipo han existido aun entre los sistemas jurisprudenciales del common law. En los Estados Unidos, el efecto vinculante horizontal — que sujeta al tribunal a su propio precedente - no ha sido una regla rígida, como sí lo fue en Inglaterra desde finales del siglo XIX hasta $1966 .{ }^{35} \mathrm{E}$ incluso puede decirse que es más corta de lo que aparenta la distancia entre los "dos modelos básicos de incorporación de normas de origen judicial", el "precedente" anglosajón y la "jurisprudencia" (por reiteración) romanista: en el primero pueden elaborarse líneas por la concatenación de diversos precedentes, y el último supone como elemento mínimo la existencia de precedentes aislados y sus rationes decidendi. ${ }^{36}$

En la actualidad, quizá presenciamos la incipiente formación de una "teoría general del precedente", que trasciende culturas jurídicas, y éste es uno de los puntos en que la tradición neorromanista se aproxima a la del common law. ${ }^{37}$ La discusión entre estas tradiciones en torno al precedente es propicia para elaborar una porción de un "derecho intercultural" que contenga postulados comunes a ambas culturas jurídicas, ${ }^{38}$ pero por su grado de desarrollo me parece claro que este terreno común deberá cimentarse sobre los postulados que al respecto ha formulado la tradición anglosajona.

Sobre lo anterior hay un punto insoslayable: la necesidad de adoptar un enfoque decididamente comprehensivo y flexible del concepto de "precedente" y del stare decisis. ${ }^{39}$ Michele Taruffo abunda sobre esta inquietud:

Parece, sin embargo, evidente la falta de adecuación de una teoría general del precedente que sea sólo una versión adaptada de la teoría (o de una teo-

tín, La creación judicial del derecho y el precedente vinculante, Cizur Menor (Navarra), Aranzadi-Thomson Reuters, 2011, p. 233.

35 Garner et al., op. cit., nota 8, p. 35.

36 Aguiló Josep, "Fuentes del derecho", en J. Fabra Zamora y V. Rodríguez-Blanco (eds.), Conceptos jurídicos fundamentales y aplicación del derecho, Madrid, UNAM (en prensa), citado por Atienza, Manuel, Curso de argumentación jurídica, Madrid, Trotta, 2013, pp. 332 y 333.

37 Y por su parte, la tradición anglosajona se acerca a la continental en su "mayor confianza en los códigos y [en] el derecho estatutario". MacCormick y Summers, op. cit., nota 5, p. 496.

38 López Medina, op. cit., nota 30, p. 134, y Rivero Evia, Jorge, Fundamentos de derecho intercultural, México, Tirant lo Blanch, 2017, pp. 46 y 47.

39 Bankowski, Zenon et al., "Los fundamentos del precedente", en MacCormick y Summers (eds.), op. cit., nota 5, p. 461. 
ría) del precedente del common law. Una teoría del precedente que aspire a ser general y, por tanto, a tener cualquier utilidad heurística en más [de] un ordenamiento, debería por el contrario partir de la premisa de que el precedente existe en ordenamientos histórica y estructuralmente diferentes, y que el mismo presenta características diferentes en los distintos ordenamientos. Tal teoría debería servirse de conceptos amplios y diferenciados, capaces de conducir a una relativa unidad de fenómenos que representan múltiples peculiaridades. ${ }^{40}$

En efecto, actualmente no contamos con una "teoría general" del precedente judicial que sea cabal y con pretensiones de aplicabilidad universal; en el mejor de los casos, sólo puede decirse que ésta se halla "en construcción". Tal teoría general no podrá elaborarse de la noche a la mañana, ni veremos en los próximos años un esbozo de sus características esenciales. ${ }^{41}$ Pero como muestro más adelante, ya se han identificado conceptos $y$ funciones básicos del precedente judicial, que resultan comunes a diversos sistemas y tradiciones jurídicas, ${ }^{42}$ y que permitirían traer los postulados generales elaborados al respecto por el common law a nuestra cultura romanista, y en particular al sistema jurídico mexicano, aunque con la precaución que sugiere Taruffo.

\section{Fundamento constitucional}

Se han expresado muy diversas razones para que los tribunales sigan sus propios precedentes (efecto vinculante horizontal) o los que establecieron otros de nivel superior (efecto vinculante vertical). ${ }^{43}$ En realidad, antes que

40 Cinco lecciones mexicanas. Memoria del Taller de Derecho Procesal, México, TEPJF, 2003, disponible en: http://bit.ly/2I9Q44M, p. 195 (énfasis añadido).

41 La importante obra que coordinaron MacCormick y Summers (op. cit., nota 5) fue un gran esfuerzo para advertir similitudes entre culturas y sistemas jurídicos con relación al precedente judicial. Pero considerando que su versión original en inglés (Interpreting Precedents: A Comparative Study, Brookfield, Ashgate, 1997) tiene más de veinte años, sin que en éstos se haya dado algún avance significativo en este sentido, no parece probable que veamos el acelerado progreso de una visión compartida sobre el precedente.

42 Gómora Juárez, op. cit., nota 10, pp. 31-33.

43 Sobre los efectos horizontal y vertical del precedente, dicotomía empleada desde los años ochenta del siglo pasado, véase Garner et al., op. cit., nota 8, pp. 27 y ss. Cfr. Gascón Abellán, Marina, "Autoprecedente y creación de precedentes en el Tribunal Supremo”, en Bernal Pulido, Camarena González y Martínez Verástegui (coords.), op. cit., 
por uno solo, el vigor de los precedentes judiciales se explica - y conviene hacerlo- por una combinación de factores con el protagonismo de alguno de ellos en relación con el tipo de precedente de que se trate. ${ }^{44}$ Estos factores pueden basarse en principios jurídicos esenciales al derecho, que incluso se han consagrado como derechos fundamentales, al igual que en la conveniencia de la eficiencia del ordenamiento jurídico. ${ }^{45}$

Como una aproximación inicial, entre los primeros contaré la seguridad jurídica —y sus implicaciones_-, la igualdad en la aplicación de la ley y la imparcialidad judicial; y los segundos a muy grandes rasgos pueden cifrarse en la economía que para los casos particulares conlleva la respuesta previamente "examinada y aceptada" que representa el precedente. ${ }^{46}$ Estos

nota 10, p. 213 (con mayor precisión conceptual al distinguir el "autoprecedente" y el "precedente horizontal" [referente a los emitidos por tribunales homólogos]); y Bernal Pulido, Carlos, "La anulación de sentencias y el defecto sustantivo por desconocimiento del precedente. Dos propuestas de reforma del derecho mexicano para garantizar el respeto del precedente", en idem, p. 186 (repite la clasificación de la anterior autora sin referirla).

44 Caminker, Evan H., "Why Must Inferior Courts Obey Superior Court Precedents?", Stanford Law Review, Stanford, vol. 46, núm. 4, abril de 1994, disponible en: http://bit. ly/2JPJ4ci, p. 873 (concluye luego de una meticulosa crítica de las razones a favor y en contra del stare decisis), núm. 4 (Apr., 1994, vol. 46, núm. 4 (Apr., 1994), pp. 817-873, vol. 46, núm. 4 (Apr., 1994), pp. 817-873

45 Bankowski, MacCormick, Morawsky y Ruiz Miguel, op. cit., nota 39, pp. 453 y 455. Véase también Orozco Muñoz, op. cit., nota 34, pp. 231-240 (expone "[c]uatro principios sustantivos" [seguridad jurídica, igualdad, interdicción de la arbitrariedad e imparcialidad] y "cinco criterios de conveniencia técnica" [economía en la decisión, economía en la justificación, previsibilidad de la confirmación de la sentencia, y enervación de la prevaricación y del error judicial]).

46 Alexy, op. cit., nota 33, pp. 329 y 338. Aunque amerita diversas precisiones imposibles de realizar aquí, véanse "RECLAMACIÓN. PROCEDE IMPONER MULTA AL RECURRENTE BAJO LA HIPÓTESIS DE INTERPOSICIÓN SIN MOTIVO, CUANDO EN LAS CONSIDERACIONES DEL AUTO RECURRIDO SE CITE UNA JURISPRUDENCIA EXACTAMENTE APLICABLE AL CASO PARA JUSTIFICAR SU SENTIDO Y QUE NO HA SIDO INTERRUMPIDA", Primera Sala, Semanario Judicial de la Federación y su Gaceta, 10a. época, lib. IX, junio de 2012, t. 1, tesis 1a./J. 7/2012 (9a.), p. 139; “CONCEPTOS DE VIOLACIÓN INOPERANTES. LO SON AQUELLOS CUYO ANÁLISIS ES INNECESARIO CUANDO SOBRE EL TEMA PLANTEADO EN ELlOS YA EXISTE JURISPRUDENCIA DE LA SuPREMA CORTE DE JUSTICIA DE LA NACIÓN", Gaceta del Semanario Judicial de la Federación, 10a. época, lib. 33, agosto de 2016, t. IV, tesis I.6o.T. J/30 (10a.), p. 2305; y “CONCEPTOS DE VIOLACIÓN INOPERANTES. RESULTA INNECESARIO SU ANÁLISIS, CUANDO SOBRE EL TEMA DE FONDO PLANTEADO EN LOS MISMOS YA EXISTE JURISPRUDENCIA", idem, 10a. época, lib. 35, octubre de 2016, t. IV, tesis XVII.1o.C.T. J/9 (10a.), p. 2546. 
aspectos son dimensiones inescindibles del precedente; corresponden a diferentes valores que se realizan simultáneamente mediante la aplicación jurisprudencial.

Al lado de estos valores se han reconocido como propósitos que justifican la eficacia vinculante del precedente: 1) la economía producida por la simplicidad que tiene el tribunal de ajustarse a una respuesta previamente existente, y 2) lo deseable que resulta admitir que los tribunales tienen el poder de crear normas jurídicas para actualizar, mejorar y completar el ordenamiento. ${ }^{47} \mathrm{Sin}$ negar que ambos fines adquieren importancia en ciertos contextos, ellos no son generalmente admitidos como fundantes del principio stare decisis.

En relación con el precedente, la seguridad jurídica se despliega de varias maneras, como también corresponde a las múltiples vertientes de este principio. El apoyo en criterios judiciales previamente establecidos contribuye a la unidad y a la coherencia del ordenamiento jurídico bajo una interpretación común del derecho que permite unificar las opiniones sobre el significado de la ley, y que abona a la predictibilidad de la aplicación jurídica. ${ }^{48}$ Consecuentemente, esta unificación impide que el juez del nuevo caso imponga arbitrariamente su decisión, por hallarse constreñido en principio a seguir el precedente, lo que a su vez hace previsible su decisión y precisa las expectativas de los justiciables sobre su situación jurídica. ${ }^{49}$

La uniformidad anterior hace que el principio stare decisis sea manifestación de la igualdad en la aplicación de la ley, ${ }^{50}$ en tanto dispone que

47 Respectivamente, Gascón Abellán, op. cit., nota 43, pp. 212 y 213, y Gómora Juárez, op. cit., nota 10, pp. 118 y 119. El desarrollo judicial del derecho (Rechtsfortbildung) es una función judicial perfectamente reconocida en Alemania; por todos véase Larenz, Karl, Metodología de la ciencia del derecho, 2a. ed., trad. de M. Rodríguez Molinero, Barcelona, Ariel, 2001, pp. 359-363.

48 Ferreres Comella, op. cit., nota 16, p. 44, y Bankowski, MacCormick, Morawsky y Ruiz Miguel, op. cit., nota 39, pp. 451-453. En particular, véase "SEGURIDAD JURÍDICA EN MATERIA TRIBUTARIA. EN QUÉ CONSISTE”, Primera Sala, Semanario Judicial de la Federación y su Gaceta, 10a. época, lib. XVI, enero de 2013, t. 1, tesis 1a./J. 139/2012 (10a.), p. 437.

49 Orozco Muñoz, op. cit., nota 34, p. 232, y Garner et al., op. cit., nota 8, pp. 11 y 12.

50 Bankowski, MacCormick, Morawsky y Ruiz Miguel, op. cit., nota 39, p. 453; Ollero, Andrés, Igualdad en la aplicación de la ley y precedente judicial, 2a. ed., Madrid, Centro de Estudios Políticos y Constitucionales, 2005, p. 23; Pérez Portilla, Karla, Principio de igualdad. Alcances y perspectivas, México, UNAM-Conapred, 2005, p. 70; y "AMPARO DIRECTO EN REVISIÓN. ES PROCEDENTE CUANDO EL TRIBUNAL COLEGIADO INAPLICA UNA JURISPRUDENCIA EMITIDA POR LA SUPREMA CORTE DE JUSTICIA DE LA 
"los litigantes en situaciones similares deben ser tratados igualmente"; 51 por ello, su mandato de observancia del precedente puede tenerse por "un principio común a cualquier sistema jurídico" que reconozca jurídicamente aquel valor. ${ }^{52}$ Este aspecto no está claramente reconocido como fundamento del efecto vinculante del precedente en el common law-por lo menos en su versión norteamericana, pese a la trascendencia de la cláusula de protección igualitaria de la enmienda XIV de su Constitución- - ${ }^{53}$ en cambio, paradójicamente, la creciente cercanía de la cultura romanista a la orientación fáctica de aquella tradición combinada con la relevancia que tiene el principio de igualdad en la nuestra, al parecer ha ocasionado el protagonismo en el terreno romanista de una visión influida por este valor fundamental, según la cual la fidelidad al precedente buscaría particularmente "asegurar que bajo iguales circunstancias las personas reciban trato igual". ${ }^{54}$ En México, la Suprema Corte de Justicia de la Nación señaló la "igualdad ante la ley" como fundamento del deber general de los tribunales de "no modificar arbitrariamente sus decisiones en casos que compartan la misma litis, salvo cuando consideren que deben apartarse de sus precedentes". ${ }^{5}$

Aunque más frecuentemente invocado en el ámbito anglosajón, un tercer argumento para fundar el recurso a los precedentes judiciales estriba en que promueve la imparcialidad judicial. La trascendencia que tendrá el

NACIÓN", Primera Sala, Gaceta del Semanario Judicial de la Federación, 10a. época, lib. 5, abril de 2014, t. I, tesis 1a. CXXXIX/2014 (10a.), p. 789.

51 James B. Beam Distilling Co. v. Georgia, 501 U.S. 529, 538 (1991).

52 Orozco Muñoz, op. cit., nota 34, pp. 232 y 233.

53 Garner et al., op. cit., nota 8, pp. 6-12, 21 y 106 (omitie el principio de igualdad entre las bases del stare decisis, pero señala como su fin último "que los problemas jurídicos recurrentes se[an] abordados de manera similar — se[an] tratados de modo igual [equally]_").

54 López Medina, op. cit., nota 30, pp. 233 y 238; Ferreres Comella, op. cit., nota 16, p. 45; Xiol Ríos, Juan Antonio, "Notas sobre la jurisprudencia", en Ferreres Comella e idem, El carácter vinculante de la jurisprudencia, México, Fundación Coloquio Jurídico Europeo-Fontamara, 2010, pp. 99 y 102, y Bankowski, MacCormick, Morawsky y Ruiz Miguel, op. cit., nota 39, pp. 453 y 454.

55 "DEREChO HUMANO A LA IGUALDAD JURÍDICA. RECONOCIMIENTO DE SU DIMENSIÓN SUSTANTIVA O DE HECHO EN EL ORDENAMIENTO JURídiCo MEXICANO”, Primera Sala, Gaceta del Semanario Judicial de la Federación, 10a. época, lib. 49, diciembre de 2017, t. I, tesis 1a./J. 125/2017 (10a.), p. 121. Véase también "IGUALDAD. LÍMITES A ESTE PRINCIPIO", Primera Sala, Apéndice al Semanario Judicial de la Federación y su Gaceta 1917- 2011, t. I, tesis 15, p. 835. 
criterio jurídico de su sentencia orillaría al tribunal a resolver el caso particular con máxima objetividad y corrección, desde una visión general que se aparte de las particularidades del caso concreto, pues desconoce las circunstancias en que se darán los casos futuros y quiénes serán sus partes. ${ }^{56}$ De esta manera, el stare decisis promovería el "respeto por la judicatura como una fuente [jurídica] neutral", ${ }^{57}$ porque la obligaría a serlo.

Pero además, la vinculación al precedente "blindaría" la independencia y la imparcialidad de los tribunales, lo cual —en la modalidad de "autoprecedente" - es particularmente importante para la legitimidad de las decisiones de sedes judiciales terminales, en particular las encargadas de la interpretación definitiva de la Constitución. ${ }^{58}$ Esta sujeción - y sobre todo el desarrollo técnico de los procedimientos que operen sus variaciones $^{59}$ - dificultaría que adopten decisiones a modo, pues tras él podrían parapetarse los órganos jurisdiccionales ante las presiones que se les dirigieran. Por ende, lejos de suponer una debilidad para los tribunales o un óbice para ejercer sus funciones, la vinculación a sus precedentes fortalece a la judicatura en tanto que "la medida de su poder es su capacidad de determinar de antemano los comportamientos de los sujetos a través de la producción de reglas generales, y esta capacidad depende enteramente de la coherencia y de la estabilidad de su jurisprudencia", ${ }^{60}$

56 Ferreres Comella, op. cit., nota 16, p. 46.

57 Garner et al., op. cit., nota 8, p. 10.

58 Ezquiaga Ganuzas, Francisco Javier, La argumentación en la justicia constitucional y otros problemas de aplicación e interpretación del derecho, México, TEPJF, 2006, disponible en: http://bit.ly/1BXZGEc, p. 336.

59 Lo que en México ejemplifica el recurso (a veces implícito) a la "nueva reflexión" de la Suprema Corte. Véanse por ejemplo "Prisión VITALICIA. CONSTITUYE UNA PENA INUSITADA DE LAS PROHIBIDAS POR EL ARTíCULO 22 CONSTITUCIONAL”, Pleno, Semanario Judicial de la Federación y su Gaceta, 9a. época, t. XIV, octubre de 2001, tesis P./J. 127/2001, p. 15; "PRISIÓN VITALICIA. NO ES UNA PENA INUSITADA Y TRASCENDENTAL, POR LO QUE NO VIOLA LA CONSTITUCIÓN FEDERAL", Pleno, idem, 9a. época, t. XXIII, febrero de 2006, tesis P. XIX/2006, p. 1178; "Prisión VITALICIA. No CONSTITUYE UNA PENA INUSITADA DE LAS PROHIBIDAS POR EL ARTÍCULO 22 DE LA CONSTITUCIÓN POLÍTICA De los Estados Unidos MeXiCAnos", Pleno, idem, 9a. época, t. XXIII, febrero de 2006, tesis P./J. 1/2006, p. 6; y Redacción, "El artífice de las extradiciones", Proceso, México, 28 de enero de 2007, disponible en: http://bit.ly/2ysk6g6 (5 de octubre de 2017).

60 Troper, Michel, "Le positivisme et les droits de l'homme", Le droit et la nécessité, París, Presses Universitaires de France, 2011, p. 43. Véanse también Breyer, Stephen, Making our Democracy Work: A Judge's View, Nueva York, Vintage Books, 2010, pp. 149,151 y 156 (resalta la estabilidad de los criterios judiciales como factor para preservar 
De lo anterior puede desprenderse una conclusión muy importante: en ordenamientos que cuentan la igualdad en la aplicación de la ley, la seguridad jurídica y la imparcialidad judicial entre sus principios fundamentales - como el mexicano-, es innecesaria una disposición constitucional o legislativa que especifique la obligatoriedad del precedente judicial para que éste adquiera efecto vinculante en alguna medida. ${ }^{61} \mathrm{~A}$ mi juicio, ni siquiera se requeriría dicha disposición para compaginar el empleo jurisprudencial con nuestro muy estimado principio de legalidad; ${ }^{62}$ para esto último bastarán tales principios jurídicos generales, especialmente si gozan — como sucede entre nosotros — de rango constitucional. ${ }^{63}$ No podría negarse la conveniencia de la existencia de tal disposición y la de sus de-

la "fuerza institucional" de los tribunales por contribuir a su legitimidad, a la confianza en ellos y a la aceptación de sus decisiones); Alexy, op. cit., nota 33, p. 338 (dice que "[a]segurando la estabilidad [del ordenamiento], la utilización de precedentes resulta asimismo en una contribución a... la protección de la confianza en la jurisdicción [Rechtsprechung]"); y Saavedra Herrera, Camilo Emiliano, "El poder de la jurisprudencia. Un análisis sobre el desarrollo y funcionamiento del precedente judicial en México", en Bernal Pulido, Camarena González y Martínez Verástegui (coords.), op. cit., nota 10, p. 291 (alude a la teoría de la path dependence con relación a "generar y preservar la autoridad de los órganos de justicia como cuerpo").

61 Ferreres Comella, op. cit., nota 16, p. 75 (afirma la necesidad de la jurisprudencia para satisfacer dichos principios); Wróblewski, Jerzy, Sentido y hecho en el derecho, trad. de Francisco Javier Ezquiaga Ganuzas y Juan Igartua Salaverría, México, Fontamara, 2003, p. 312 (alude a "fuertes argumentos, prácticos e ideológicos" en este sentido); Gómora Juárez, op. cit., nota 10, pp. 110 y 111, y Díez, Silvia, El precedente administrativo. Fundamentos y eficacia vinculante, Madrid, Civitas, 2008, p. 108, citado por Gascón Abellán, op. cit., nota 43, p. 213 (núm. 8). Por tanto, sería equivocado pensar que la ausencia de apoyo constitucional explícito lleve a tener por irregulares las disposiciones que establecen y regulan la jurisprudencia de tribunales diferentes a los del Poder Judicial de la Federación, opinión que sostienen Zertuche García, op. cit., nota 7, p. 193; y a grandes rasgos, "JUNTA FEDERAL DE CONCILIACIÓN Y ARBITRAJE. AL NO ESTAR FACULTADA PARA INTEGRAR JURISPRUDENCIA, LOS CRITERIOS CON LOS QUE PRETENDE ESTABLECER REGLAS ORIENTADORAS O INTERPRETAR LA LEY NO SON OBLIGATORIOS, EN TÉRMINOS DE LOS ARTÍCUlos 192 Y 193 DE LA LEY DE AMPARO”, Semanario Judicial de la Federación y su Gaceta, 10a. época, lib. XIX, abril de 2013, t. 3, tesis I.6o.T.41 L (10a.), p. 2173.

62 Como expresa Orozco Muñoz, op. cit., nota 34, p. 241.

63 Garner et al., op. cit., nota 8, p. 7; y acuerdo general plenario 4/1996, Semanario Judicial de la Federación y su Gaceta, 9a. época, t. IV, septiembre de 1996, pp. 773 y ss. (dispone tener por jurisprudencia vinculante los criterios sentados al resolverse recursos de reclamación y de queja en controversias constitucionales y acciones de inconstitucionalidad). 
rivadas, y la utilidad de sus precisiones; pero ante la vigencia y supremacía de los referidos principios - aun derechos - fundamentales, no se requieren dichas disposiciones para que exista la obligación de los jueces de atenerse de alguna manera a los criterios jurídicos que ellos mismos o los de rango superior han establecido en sus decisiones.

\section{EL SISTEMA JURISPRUDENCIAL FEDERAL EN MÉXICO}

\section{Apuntes históricos}

Aunque hubo precursores - Ignacio Mariscal y Benito Juárez-,${ }^{64}$ la paternidad de nuestro sistema jurisprudencial se debe sin duda a Ignacio L. Vallarta. El jurista jalisciense sostuvo ambiciosos ideales para el sistema jurídico mexicano y la Suprema Corte de Justicia. Su admiración por los "sabios jueces norteamericanos" 65 le hizo expresarse de esta manera al comparar su ordenamiento con el nuestro:

Así lo han entendido los norteamericanos, y con ménos leyes orgánicas que las que nosotros pedimos, y con más vacíos en su Constitucion que los que la nuestra contiene, poseen en las ejecutorias de sus tribunales la jurisprudencia constitucional más completa que un pueblo puede desear. Allá una opinion de Marshall vale tanto como una ley, y leyes son los leading cases, resueltos por sus tribunales. Centenares de ejecutorias pudieran citarse que fundan sus resoluciones, no en leyes que no existen, sino en ejecutorias anteriores que dirimieron la cuestion constitucional de que se trata... ¿Por qué entre nosotros pasa lo contrario y se dice que las ejecutorias de la Corte no son ni autoridad ni doctrina para resolver casos semejantes?... Confiemos en que mejor conocidos los fines del amparo, no se siga creyendo que él se limita a proteger á un individuo, sino que se comprenda que se extiende á

64 González Oropeza, Manuel, La jurisprudencia: Su conocimiento y forma de reportarla, México, SCJN, 2005, p. 46.

65 Véase en general Mirow, Matthew C., "Marbury in Mexico: Judicial Review's Precocious Southern Migration", Hastings Constitutional Law Quarterly, San Francisco, vol. 35, núm. 1, 2007, disponible en: http://bit.ly/2y3jwlP, pp. 55-65 (trad. de Rubén Sánchez Gil e Isaac Josué Cervantes Castro: “Marbury en México: La precoz migración de la judicial review al sur”, en González Oropeza, Manuel y Báez Silva, Carlos [coords.], El “amparo Justo Prieto”. El control desconcentrado de la constitucionalidad. Homenaje al ministro José de Jesús Gudiño Pelayo, México, SCJN, 2016, pp. 454-469). 
fijar el derecho público por medio de la interpretacion que hace de la ley fundamental. ${ }^{66}$

Pudo Vallarta hacer derecho positivo de sus anteriores ideas. El 15 de agosto de 1881 dirigió a Ezequiel Montes, entonces secretario de Justicia e Instrucción Pública, la versión definitiva del proyecto de Ley de Amparo, con el cual cumplió el encargo que dicho funcionario le hizo al respecto, quien lo presentó al Senado de la República "como epílogo de su obra titulada «El juicio de amparo y el writ of habeas corpus»" ${ }^{67}$ Las principales ideas de ese proyecto legislativo que incumben a nuestro tema, fiel reflejo no sólo de las posturas de Vallarta, sino de sus mismos hábitos profesionales, son las siguientes: los jueces de distrito fundarán sus sentencias en el texto constitucional, para cuya "debida inteligencia" atenderán a las ejecutorias de la Suprema Corte y a las "doctrinas de los autores" (artículo 37); es deber de "los Tribunales" — incluyendo a la Suprema Corte — al "fijar el Derecho Público", considerar a la Constitución, "las ejecutorias que la interpreten", las leyes "emanadas de ella" y los tratados internacionales (artículo 50); y establece sanciones para los jueces que resuelvan un juicio de amparo "contra su interpretación fijada por la Suprema Corte, por lo menos en cinco ejecutorias uniformes" (artículo 73; cursivas añadidas). Salvo el segundo de los preceptos referidos, las anteriores disposiciones pasaron sin mayor cambio a los artículos 34 y 70 de la Ley de Amparo de 1882, que fueron los primeros en regular la obligatoriedad de la jurisprudencia en México. ${ }^{68}$

Lo anterior esclarece un punto muy importante de la historia de nuestro sistema jurisprudencial. Original y muy claramente, las ejecutorias de la Corte vinculaban a los jueces de distrito, y su reiteración sencillamente les daba una obligatoriedad "reforzada". Pero el artículo 786 del Código Federal de Procedimientos Civiles de $1908^{69}$ impuso como "jurispruden-

66 "Amparo pedido contra la sentencia injusta de un juez en negocio civil", Votos, México, Imprenta de Fco. Díaz de León, 1883, t. IV (5a. ed. facsimilar, Obras, México, Porrúa, 1989, t. IV), pp. 497-498 (se respetaron la ortografía y las cursivas del original).

67 Véase el "Apéndice 2" de la edición facsimilar de dicho ensayo de Vallarta, contenida en el tomo V de sus Obras publicadas por la Editorial Porrúa, que contiene la carta dirigida por este jurista al secretario Montes con su proyecto legislativo, al igual que la iniciativa presentada por dicho funcionario.

68 Véase en general Álvarez Montero, José Lorenzo, 150 años de legislación de amparo (1847-1997), Xalapa, Instituto Mexicano del Amparo, 1997, pp. 155 y ss.

69 Ibidem, p. 230. 
cia" sólo aquellos criterios reiterados en cinco ejecutorias y dio cabida a la idea de poderse negar sujeción a aquellos sin esa calidad. No obstante, el precepto siguiente del mismo ordenamiento estableció que la Suprema Corte "respetará sus propias ejecutorias", debiendo expresar sus razones cuando pretendiera apartarse de la opinión sentada en ellas - expresando así el principio de inercia que subyace al stare decisis-.

Las sucesivas leyes que rigieron el juicio de amparo (1919, 1936 y 2013), a las que luego se les agregó la reglamentaria de las fracciones I y II del artículo 105 constitucional, desarrollaron este sistema hasta que se convirtió en el imperante en la actualidad.

\section{Regulación vigente}

El undécimo párrafo del artículo 94 de la Constitución dispone que "[1] a ley fijará los términos en que sea obligatoria la jurisprudencia que establezcan los Tribunales del Poder Judicial de la Federación y los Plenos de Circuito sobre la interpretación de la Constitución y normas generales". La jurisprudencia en México tiene entonces un fundamento constitucional explícito y específico. Sin embargo, como ya manifesté, los términos con que se ha reconocido el principio de igualdad en la aplicación de la ley hacen que no se requiera cláusula constitucional o legal que imponga expresamente la observancia de la jurisprudencia. ${ }^{70}$ Aunque también señalé que por supuesto es preferible que este efecto vinculante se halle claramente establecido en una disposición constitucional o legal.

Por su parte, el artículo 177 de la Ley Orgánica del Poder Judicial de la Federación dispone esencialmente que la jurisprudencia de la Suprema Corte de Justicia de la Nación y de los tribunales colegiados de circuito se regirá por las disposiciones de la Ley de Amparo, "salvo en los casos en que la ley de la materia contuviera disposición expresa en otro sentido". Los numerales 215 a 230 de la Ley de Amparo vigente contienen las disposiciones generales que rigen la jurisprudencia en los términos del precepto anteriormente citado. Y los artículos 43 y 73 de la Ley Reglamentaria de las Fracciones I y II del Artículo 105 Constitucional prescriben lo relativo a la jurisprudencia que sienta la Suprema Corte de Justicia de la Nación a través de los procedimientos que establecen esas porciones

70 Supra, § II.4. 
de la ley fundamental. Y los artículos 232 a 235 de la referida ley orgánica rigen la jurisprudencia del Tribunal Electoral del Poder Judicial de la Federación.

De acuerdo con los preceptos anteriores, la Suprema Corte, los tribunales colegiados y los plenos de circuito ${ }^{71}$ pueden establecer jurisprudencia vinculante por: 1) reiteración del criterio en cinco ejecutorias no interrumpidas, dictadas en diferentes sesiones por las mayorías legalmente establecidas; ${ }^{72}$ 2) resolución de contradicciones de tesis; 3) sustitución de los criterios jurisprudenciales con motivo de un caso concreto, realizada luego de haberse resuelto éste, y 4) en su caso, haber sentado su criterio en controversia constitucional o en acción de inconstitucionalidad.

Finalmente, son muy importantes los acuerdos generales que el Pleno de la Suprema Corte ha emitido desde hace años respecto del Semanario Judicial de la Federación y la jurisprudencia en general. Su fundamento se halla en el artículo 11, fracciones XIX y XXI, de la ley orgánica judicial federal, en relación con los numerales 178 y 179 de la misma. Actualmente, los más relevantes son los números 16/2019 y 17/2019, ambos publicados el 9 de diciembre de 2019 en el Diario Oficial de la Federación, ${ }^{73}$ y tocantes, respectivamente, a la difusión exclusivamente electrónica de dicho reporte jurisprudencial, y a la elaboración, el envío y la publicación de tesis jurisprudenciales.

71 Véanse también los artículos 232 a 235 de la misma ley, relativos a la jurisprudencia del Tribunal Electoral del Poder Judicial de la Federación. Esta rama jurisdiccional, grosso modo también establece criterios vinculantes como los órganos que señalé, salvo por lo que se refiere a la sustitución. Sin embargo, llaman la atención dos cosas a su respecto: 1) su jurisprudencia stricto sensu también obliga a autoridades administrativas como el Instituto Nacional Electoral y sus homólogos locales ("JURISPRUDENCIA. LA DETERMINACIÓN DE SU VIGENCIA CORRESPONDE A LA SALA SUPERIOR”, Sala Superior, Gaceta de Jurisprudencia y Tesis en Materia Electoral, año 8, núm. 17, 2015, tesis XXXVI/2015, pp. 94-95); y 2) muchos de sus precedentes que versan sobre conceptos jurídicos generales, pese a que no vinculan a autoridades diferentes a las electorales, son sumamente ilustrativos y muy útiles.

72 Modalidad básica por ser la regla en la creación jurisprudencial. Véase Rosales Guerrero, Emmanuel Guadalupe, Estudio sistemático de la jurisprudencia, México, SCJN, 2005, p. 215.

73 Véase también el acuerdo general plenario 4/1996, cit., nota 63. El acuerdo general plenario 12/2011 dispuso las bases de la décima época jurisprudencial; la Secretaría General de Acuerdos de la Suprema Corte lo reporta como "vigente" (véase Acuerdos generales plenarios, disponible en: http://bit.ly/2DzT0UL [10 de diciembre de 2019]), pero su contenido ha sido superado por diversos instrumentos posteriores. 


\section{Evolución conceptual}

Especialmente a efecto de la mayor claridad de los párrafos posteriores, me parece necesario reiterar que, a diferencia de la nomenclatura tradicional de nuestro país, ${ }^{74}$ en este trabajo entiendo que dependiendo del contexto el vocablo "jurisprudencia" alude tanto al precedente judicial (absoluta o fuertemente) vinculante como al conjunto de precedentes globalmente considerados, sin importar su obligatoriedad (case law).

A lo largo de décadas, ha variado la concepción mexicana de la "jurisprudencia", entendida como conjunto de precedentes judiciales. Estas variaciones han ido de la mano de diferentes maneras de entender el sistema jurídico y la labor de los jueces que se han dado en el seno de la tradición jurídica romanista a lo largo del siglo $\mathrm{XX} .{ }^{75}$ Son tres las concepciones fundamentales del precedente judicial que han tenido lugar en México: 1) interpretativa o, mejor dicho, exegética; 2) integradora; y 3 ) creativa; ${ }^{76}$ muy al margen de la discusión sobre si la jurisprudencia constituye "fuente del derecho", que ha sido muy poco útil ${ }^{77}$ y ni siquiera es decisiva para caracterizar la jurisprudencia. ${ }^{78}$

Desde el primer punto de vista se considera la jurisprudencia bajo la óptica de un positivismo legalista, propio de la primera mitad del siglo pasado, según el cual "todo el Derecho debe encerrarse en las Leyes [...y] fuera de la Ley no hay criterios jurídicamente válidos”, y los jueces han de resolver conforme a un significado supuestamente inmanente - por ende, "verdadero" - del texto legal, "inquiri[endo] de la Ley la solución

74 Zertuche García, op. cit., nota 7, p. 86 (señala que el término "jurisprudencia" denomina el precedente vinculante y el de "precedente" [a secas] como correspondiente al carente de esa calidad, es decir, a las "tesis aisladas").

75 Véase en general García de Enterría, Eduardo, "La democracia y el lugar de la ley”, en idem, y Menéndez Menéndez, Aurelio, El derecho, la ley y el juez. Dos estudios, Madrid, Civitas, 2000, pp. 44-57.

76 En general, cfr. Zertuche García, op. cit., nota 7, pp. 180-188.

77 Ferreres Comella, op. cit., nota 16, pp. 73-75 (expresa que la jurisprudencia cae en una "zona de penumbra" del concepto de "fuente jurídica").

78 Así, por ejemplo, una visión jurisprudencial exegética, hoy mismo podría sostener - aunque no sin dificultades - que la jurisprudencia es "fuente formal del derecho", como en "JuRISPRUDENCIA. SU APLICACIÓN RETROACTIVA", Gaceta del Semanario Judicial de la Federación, 10a. época, lib. 30, mayo de 2016, t. III, tesis PC.IV.L. J/3 K (10a.), p. 2094. 
debida" ${ }^{79}$ Desde este punto de vista, la jurisprudencia "no es una ley [ni se equipara a ésta], sino la interpretación de ella, judicialmente adoptada"; 80 sería mera exégesis o glosa de la ley, dada a través de la declaración del "correcto" significado de sus disposiciones.

Otro enfoque muy posterior, no completamente apartado del anterior, ${ }^{81}$ ve a la jurisprudencia como un instrumento para llenar lagunas legales, es decir, para "integrarla" y no para declarar su "inexistente" significado en situaciones que no previeron sus disposiciones. ${ }^{82}$ En este sentido, de manera opuesta a una labor meramente "interpretativa", se advierte que la jurisprudencia, o al menos uno de sus tipos, "colma los vacíos de la ley, creando una norma que la complementa". ${ }^{83}$

Finalmente, en años más recientes, y aun de la mano de la creciente aceptación de una "teoría del precedente", se ha reconocido en México el aspecto generalmente creativo de la jurisprudencia, más allá de los casos en que constituye una estricta "integración" legal. ${ }^{84} \mathrm{El}$ punto central de la discusión sobre el carácter innovador de la jurisprudencia y su calidad de fuente jurídica ha sido su posible aplicación retroactiva. ${ }^{85}$ Tradicionalmen-

79 Ibidem, pp. 42-44. Véase también Laporta, op. cit., nota 27, pp. 30-32.

80 "JuRISPRUdENCIA", Primera Sala, Semanario Judicial de la Federación, 6a. época, vol. LXIX, segunda parte, reg. 260868, p. 60; y "JURISPRUDENCIA, ALCANCE DE LA", Primera Sala, idem, 6a. época, vol. LVIII, segunda parte, reg. 260342, p. 38.

81 “JuRISPRUDENCIA, CONCEPTO DE”, idem, 8a. época, t. VII, enero de 1991, reg. 223936, p. 296 (señala que la jurisprudencia es "integradora de las situaciones que no previó el legislador, adecuando la norma al caso concreto").

82 Sobre el concepto de "integración" y su diferencia con la "interpretación”, véase en general García Máynez, Eduardo, Introducción al estudio del derecho, 31a. ed., México, Porrúa, 1980, pp. 129, 130 y 366.

83 “JuRISPRUDENCIA. CONCEPTO, CLASES Y FINES", Semanario Judicial de la Federación y su Gaceta, 9a. época, t. XVIII, octubre de 2003, tesis IX.1o.71 K, p. 1039 (cursivas añadidas). Véase también "JURISPRUDENCIA. CASO EN QUE SU APLICACIÓN ESTÁ SUJETA AL PRINCIPIO DE NO RETROACTIVIDAD”, idem, 9a. época, t. XI, marzo de 2000, tesis IV.1o.P.C.9 K, p. 1002.

84 "Precedentes sobre derechos fundamentales de la Suprema CorTe DE JUSTICIA DE LA NACIÓN. LA DISTINCIÓN QUE DE ÉSTOS HACE UN TRIBUNAL COLEGIADO DE CIRCUITO CONLLEVA UNA MODIFICACIÓN DE SU INTERPRETACiÓN", Primera Sala, Gaceta del Semanario Judicial de la Federación, 10a. época, lib. 25, diciembre de 2015, tesis 1a. CCCXCIII/2015 (10a.), p. 270. Señala que la jurisprudencia entraña una "creación normativa" que "participa de cierta generalidad, abstracción e impersonalidad", pero contradictoria y primordialmente negándole carácter de "ley material". Cfr. Zertuche García, op. cit., nota 7, pp. 173, 198 y 307.

85 Ibidem, pp. 202-216 y 303-310 (particularmente la p. 305, la cual señala que el 
te, se había negado ésta —o, mejor dicho, su ilicitud — considerando que dar efecto a un criterio judicial en relación con hechos pasados no resulta retroactivo en tanto la ley que interprete siga siendo la misma; ${ }^{86}$ pero el artículo 217, último párrafo, de la vigente Ley de Amparo supone un cambio de percepción al respecto: proscribir parcialmente la natural retroactividad jurisprudencial ${ }^{87}$ para dejar sin efecto un criterio que directamente regía cuando se estableció una situación, ${ }^{88}$ implica que el criterio jurisprudencial anterior y el novedoso constituyen normas generales autónomas.

Quizá Carlos de Silva y Nava describió del modo más preciso la naturaleza del precedente judicial:

el Juez aplica una norma abstracta y la hace concreta; ... pero tan hay creación del Juez..., que cuando se vuelve a la abstracción, ya la Jurisprudencia no dice exacta y literalmente lo que decía la Ley, la Ley se adecuó a situaciones especiales; inclusive se hizo evolucionar a la propia Ley, la hizo aplicable a casos que quizá ni siquiera había previsto o podido prever el legislador[;] entonces, si vamos de lo abstracto a lo concreto y de lo concreto a lo abstracto, a través de la creación jurisprudencial, encontraremos que no volvemos al punto de partida[;] de otra manera, saldría sobrando la Jurisprudencia obligatoria. Saldría sobrando, porque sería una simple repetición de lo establecido por la norma que fue aplicada por el Juzgador. ${ }^{89}$

problema de la retroactividad jurisprudencial deriva de "autores que consideran a esta institución, dada su generalidad, abstracción e impersonalidad[,] como ley en sentido material").

86 Por todos véase "JuRISPRUDENCIA. SU APLICACIÓN NO VIOLA LA GARANTÍA DE IRRETROACTIVIDAD DE LA LEY”, Pleno, Apéndice al Semanario Judicial de la Federación 1917-2011, t. I, tesis 150, p. 1071.

87 Gómora Juárez, op. cit., nota 10, p. 92.

88 "JURISPRUDENCIA. ALCANCE DEL PRINCIPIO DE IRRETROACTIVIDAD DE AQUÉLLA TUTELADO EN EL ARTículo 217, PÁRRAFO ÚlTIMO, DE LA LEY DE AMPARO”, Segunda Sala, Gaceta del Semanario Judicial de la Federación, 10a. época, lib. 38, enero de 2017, t. I, tesis 2a./J. 199/2016 (10a.), p. 464. Parcialmente en contra, $c f r$. "USURA. AL RESOLVER EL JUICIO DE AMPARO DIRECTO, EL TRIBUNAL COLEGIADO DE CIRCUITO DEBE APLICAR LA JURISPRUDENCIA QUE ORDENA EL ESTUDIO OFICIOSO DE SU POSIBLE EXISTENCIA, NO OBSTANTE QUE EL ACTO RECLAMADO SE HAYA EMITIDO BAJO LA VIGENCIA DE UN CRITERIO INTERPRETATIVO DIFERENTE", Primera Sala, idem, lib. 36, noviembre de 2016, t. II, tesis 1a./J. 52/2016 (10a.), p. 877.

89 "La jurisprudencia”, en VV. AA., Curso de actualización de amparo, México, UNAM, Facultad de Derecho, 1975, pp. 111 y 112 (se respetaron las mayúsculas del original). 
Esta descripción se apega plenamente a un enfoque hermenéutico contemporáneo. ${ }^{90}$ En mayor o menor medida, toda interpretación jurídica es siempre una actividad creativa, ${ }^{91}$ mas no por completo, porque su resultado es un derivado de las disposiciones jurídicas a las que brinda eficacia en una situación concreta. Reformulando los términos de la disposición a la que adjudica significado, y de la cual depende, la interpretación elabora una norma análoga a ella: no la reproduce "exacta y literalmente", sino que parte de ella para concretizarla en una determinada situación. Esta nueva norma concretizada, más específica, no tiene el mismo grado de abstracción —-mejor dicho: de generalidad-que la disposición interpretada, y por eso se le ha negado equipararse a la ley; ${ }^{92}$ pero expresa también de modo general, abstracto e impersonal un supuesto más específico que el de la ley interpretada. La interpretación tiene el texto como punto de partida, pero en el curso de una "espiral hermenéutica" lo lleva a un punto diferente y más elevado: crea explícita o implícitamente una nueva norma general, abstracta e impersonal, que concretiza la disposición interpretada - y hasta podría decirse que la remplaza ${ }^{93}$ - , y que es inmediatamente aplicable a los casos particulares que actualizan su hipótesis más específica.

Esta concepción hermenéutica es particularmente útil para comprender el sistema jurisprudencial mexicano, y en especial los objetivos a que debe servir su tradicional práctica de elaboración de "tesis". De esta manera, la discusión — aparentemente bizantina por ser meramente "teórica" — sobre la naturaleza de la jurisprudencia puede tener importantes repercusiones prácticas en México.

\footnotetext{
90 Véase en general Sánchez Gil, Rubén Antonio, Los principios de la interpretación constitucional y su aplicación por la Suprema Corte de Justicia de la Nación, tesis de doctorado, México, UNAM, Facultad de Derecho, 2008, disponible en: http://bit. ly/ljeqGWK, pp. 15-33; e infra, nota 96.

91 Supra, nota 4.

92 Zertuche García, op. cit., nota 7, pp. 198 y 199.

93 Gómora Juárez, op. cit., nota 10, p. 131. De ahí la vertiente del realismo jurídico que identifica el "derecho" con las resoluciones de los tribunales; véase García Máynez, Eduardo, Positivismo jurídico, realismo sociológico y iusnaturalismo, 4a. ed., México, UNAM, Facultad de Derecho, 1997, p. 89.
} 


\section{Dos PROBLEMAS MEXICANOS}

\section{Ejecutoria, precedente y tesis}

\section{A. Ratio decidendi, holding y obiter dictum}

Es generalizado distinguir las secciones de la sentencia que contiene un precedente con los conceptos de ratio decidendi y obiter dictum. ${ }^{94}$ Esta distinción ha sido elaborada en el ámbito anglosajón, y tiene en él un papel muy destacado. Sin embargo, aunque con mucha menor relevancia, también se le halla en sistemas de otras familias jurídicas - como la nuestra-, o ha sido rudimentaria o informalmente reconocida en ellos. ${ }^{95}$

Esencialmente, la ratio decidendi ("razón de la decisión") es el principio o regla jurídica especifica que sirvió de base a la decisión del tribunal de modo determinante. Se trata de la norma jurídica resultante de la interpretación judicial que reformula un texto legislativo para establecer de modo abstracto las consecuencias que deben realizarse ante un supuesto consistente en los hechos particulares del caso, y que sirve de premisa mayor al silogismo de aplicación jurídica contenido en la decisión del tribunal. ${ }^{96}$ La ratio es la parte de la resolución judicial a la que se atribuye efecto vinculante, y que controlará — por su carácter abstracto — la decisión interpretativa que haya de adoptarse en casos futuros. ${ }^{97}$

94 En lo sucesivo, véanse en general Garner et al., op. cit., nota 8, pp. 44-48; Orozco Muñoz, op. cit., nota 34, pp. 27-30; Zertuche García, op. cit., nota 7, p. 53; López Medina, op. cit., nota 30, pp. 217-220 y 231-237; Taruffo, op. cit., nota 40, pp. 199-200; Rabasa, op. cit., nota 19, pp. 555-557; y Magaloni, Ana Laura, El precedente constitucional en el sistema judicial norteamericano, Madrid, McGraw-Hill, 2001, pp. 81-83.

95 Marshall, Geoffrey, "Lo vinculante del precedente", en MacCormick y Summers (eds.), op. cit., nota 5, pp. 470-473.

96 Sánchez Gil, op. cit., nota 90, pp. 19-22 y 33. Cfr. "JURISPRUDENCIA. SU APLICACIÓN NO PUEDE CONSIDERARSE VIOLATORIA DEL PRINCIPIO DE IRRETROACTIVIDAD, EN TANTO QUE EL HECHO A REGULAR O SITUACIÓN PROCESAL A RESOLVER SEA POSTERIOR A LA VIGENCIA DE LA LEY (INTERPRETACIÓN DEL ARTÍCULO 217, ÚLTIMO PÁRRAFO, DE LA LEY DE AMPARO)", Gaceta del Semanario Judicial de la Federación, lib. 12, noviembre de 2014, t. IV, tesis I.3o.C.54 K (10a.), p. 2995.

97 Larenz, op. cit., nota 47, pp. 429, 430 y 432 (subraya que "[n]o está prejuzgada la resolución del caso particular que ha adquirido fuerza jurídica", sino sólo "la respuesta dada por el tribunal, en el marco de la fundamentación del juicio", pues el aspecto vinculante del precedente consiste en una "máxima de decisión... en cuanto se refiere a una 
En los Estados Unidos se prefiere utilizar el término holding para aludir a "lo establecido o sostenido" por el tribunal, y es habitual tenerlo por sinónimo de la locución ratio decidendi, que se emplea más en Inglaterra. ${ }^{98}$ Pero en realidad no hay identidad en los significados precisos de estas expresiones, y su diferencia, aunque sutil, puede servir para conocer con mayor precisión la naturaleza del precedente. El holding es la determinación que el tribunal realizó concretamente en su resolución - las palabras "exactas" de la sentencia, por así decirlo — $; 99$ en cambio, la ratio decidendi es la formulación abstracta y general del principio en que se basa dicha determinación judicial, y del cual ésta y lo sostenido en ella serían una aplicación concreta. ${ }^{100}$

La ratio decidendi y el holding se sobreponen, y por eso se confunden con tanta facilidad; pero se requieren mutuamente, y por eso aquélla debe tenerse por formulada implícitamente por lo menos. ${ }^{101}$ Como principio general abstracto, la ratio decidendi no trasciende el ámbito ideal, por sí misma carece de efecto jurídico, porque es una mera hipótesis interpretativa, o incluso un simple ejercicio especulativo; lo que le da vida como precedente vinculante es su actualización a través del holding expresado en los precisos términos de la resolución judicial, de la cual surge la necesidad jurídica de reiterar su empleo en casos futuros y dar a éstos el mismo trato, conforme al principio de igualdad en la aplicación de la ley, necesidad que no surgiría en relación con una norma jurídica hipotética. ${ }^{102} \mathrm{Y}$ de acuerdo con el principio de universabilidad (Universalisierbarkeit), cuya observancia es elemento esencial de su corrección material, la decisión

interpretación 'acertada' o [a un] complemento de normas, o concretiza un principio jurídico de modo paradigmático"). Véase también Vallarta, Ignacio L., El juicio de amparo y el "writ of habeas corpus". Ensayo crítico-comparativo sobre esos recursos constitucionales, México, Imprenta de Fco. Díaz de León, 1881 (4a. ed. facsimilar, Obras, México, Porrúa, 1989, t. V), pp. 320-322 (expone que "se confunde la resoluci[ó]n de la sentencia con sus fundamentos", y pone de relieve a la Corte como "final intérprete de [la] suprema ley" y que entre los "fines del amparo" está "fijar el derecho público por medio de la interpretaci[ó]n que [dicho tribunal] hace de la ley fundamental").

98 López Medina, op. cit., nota 30, p. 215 (n. 20), y Magaloni, op. cit., nota 94, pp. 81 y 92 (n. 63).

99 Ibidem, p. 81 (señala que "el holding es la respuesta que el tribunal da a las partes respecto de la cuestión jurídica que el caso plantea" [cursivas en el original])

100 Garner et al., op. cit., nota 8, p. 46.

101 Gómora Juárez, op. cit., nota 10, pp. 69 y 74-76.

102 Orozco Muñoz, op. cit., nota 34, p. 30; y López Medina, op. cit., nota 30, pp. 236 y 237. 
judicial y su holding deben ser expresión de una regla general y abstracta, aplicable a todos los casos que resulten esencialmente similares al que resolvió la primera. ${ }^{103}$ Ratio decidendi y holding no son sinónimos, pero sí se refieren a conceptos estrechamente vinculados: ${ }^{104}$ abstracto y genérico el primero, y concreto e individualizado el segundo. ${ }^{105}$

A diferencia de los conceptos anteriores, el obiter dictum ("dicho de paso") se define por exclusión. Se trata de cualquier consideración en la resolución judicial que no haya determinado su resultado. Ejemplos de este elemento pueden ser: "[u]n ingenioso párrafo de apertura, la información de trasfondo relativa a cómo se desarrolló la ley, [y] las digresiones especulativas", que suelen hallarse en las sentencias. ${ }^{106}$ El hoy retirado juez Richard A. Posner sugirió una manera muy práctica para distinguir entre las porciones vinculantes de la resolución y las que no lo son: dictum sería el razonamiento que podría suprimirse de la resolución sin afectar seriamente los "fundamentos analíticos" del holding; de lo contrario, nos hallaríamos ante una ratio decidendi. ${ }^{107}$

103 Alexy, op. cit., nota 33, pp. 335 y 336. Véanse también Bulygin, Eugenio, “Los jueces ¿crean derecho?”, en Malem, Jorge, Jesús Orozco y Rodolfo Vázquez (comps.), La función judicial. Ética y democracia, Barcelona, Gedisa-TEPJF-ITAM, 2003, pp. 21-37; y Lara Chagoyán, Roberto, "El principio de universalidad en el razonamiento jurídico", Revista de la Facultad de Derecho de México, México, UNAM, t. LVII, núm. 247, enerojunio de 2007, disponible en: http://bit.ly/2yQX2Uh, pp. 221-247.

104 Un tercer concepto, próximo a los mencionados, es el rationale; relativamente común en el habla inglesa, pero a mi parecer poco empleado en relación con la jurisprudencia. El rationale es una "afirmación de razones; específ[icamente], una explicación razonada o una exposición de principios que subyacen a un arte, ciencia, procedimiento, opinión, etc. ... [También puede ser] [1] a base lógica de un procedimiento, hecho, posición, etc.” (Garner et al., op. cit., nota 8, p. 803). Se trata del porqué de la decisión del tribunal, de las razones últimas que éste tuvo para resolver como lo hizo y no de otra manera (cfr. Magaloni, op. cit., nota 98, p. 82); en una palabra, del "propósito" de la decisión del tribunal, que puede ser crucial en la aplicación —o desaplicación — futura del precedente (véase Camarena González, Rodrigo, "La derrotabilidad del precedente constitucional. A propósito de la C.T. 299/2013”, Revista del Centro de Estudios Constitucionales, México, SCJN, año III, núm. 4, enero-junio de 2017, disponible en: http://bit.ly/2J26njX, pp. 334 y 335$)$.

105 Rabasa, op. cit., nota 19, p. 556: "[E]n la práctica se advierte que en la mayoría de los casos el principio general de derecho [que podría constituir la ratio decidendi] en que se funda la decisión o resolución concreta del negocio es mucho más amplio que la decisión misma [holding]".

106 Garner et al., op. cit., nota 8, p. 44.

107 Sarnoff v. American Home Prods. Corp., 798 F.2d 1075, 1084 (7th Cir. 1986), 
Los dicta son acreedores de mucha menor deferencia; a grandes rasgos, por lo general se les niega todo efecto vinculante. La razón para ello es que al no ser fundamentales para la argumentación del tribunal, las consideraciones digresivas no determinaron la decisión, o versan sobre puntos que el tribunal no consideró detenidamente. ${ }^{108}$ Sin embargo, su inferioridad no les priva de utilidad, pues entre otros propósitos servirían para comprender mejor el curso del razonamiento judicial; así, la Suprema Corte norteamericana expresó que los obiter dicta "«pueden ser seguidos si son suficientemente persuasivos», pero no son vinculantes". ${ }^{109}$ La relativa importancia de estos elementos ha sido reconocida en México como posiciones que adopta un tribunal frente a ciertos problemas jurídicos. ${ }^{110}$

Como se les ha aplicado en los Estados Unidos, los dicta no prevalecen sobre un holding aunque sean posteriores, pero si no hubiera un precedente vinculante que regule la cuestión, un dictum "puede ser tan persuasivo como una resolución que [aún] no se haya publicado". Cuando resultan de un trabajo serio y deliberado por parte de los jueces y de su equipo, se les puede otorgar incluso mayor autoridad que a otras fuentes - como los artículos académicos y los ocursos de los litigantes_-. ${ }^{111}$

\section{B. Las tesis mexicanas}

Hay quien piensa que el sistema jurisprudencial mexicano no puede verse con la óptica de la teoría del precedente elaborada por el common law, pues no consiste en el manejo de sentencias, sino en el de tesis abstractas que elaboran nuestros órganos jurisdiccionales a partir de sus reso-

citado por ibidem, pp. 46 y 47; véase también ibidem, p. 53. Una regla similar estableció el Tribunal Constitucional Federal alemán en BVerfGE 96, 375 (404); sobre las críticas a ella, véase Schlaich, Klaus, Das Bundesverfassungsgericht. Stellung, Verfahren, Entscheidungen, 5a. ed. continuada por Stefan Korioth, Múnich, C. H. Beck, 2001, p. 327.

108 Cohens v. Virginia, 19 U.S. (6 Wheaton) 264, 399-400 (1821) (sentencia en que el great chief justice John Marshall trazó muy claramente la línea que separa los conceptos hoy denominados holding y obiter dictum).

109 Central Green Co. v. United States, 531 U.S. 425, 431 (2001) (citando Humphrey's Executor v. United States, 295 U.S. 602, 627 [1935]).

110 “CONTRADICCIÓN DE TESIS. LOS CRITERIOS JURÍDICOS EXPRESADOS «A MAYOR ABUNDAMIENTO» SON DE TOMARSE EN CUENTA PARA RESOLVER AQUÉLlA”, Pleno, Semanario Judicial de la Federación y su Gaceta, 9a. época, t. XXIV, julio de 2006, tesis P. XLIX/2006, p. 12.

111 Véase en general Garner et al., op. cit., nota 8, pp. 65-69. 
luciones. Pero esta impresión se debe más a los hábitos con que aplicamos la jurisprudencia que a una detenida reflexión sobre ésta.

El sistema de tesis abstractas que empleamos los juristas mexicanos es un buen ejemplo del carácter "conceptualista" de la jurisprudencia de países romanistas, en contraste con la orientación fáctica que distingue la de los anglosajones. ${ }^{112}$ Abstracciones semejantes las encontramos en otros sistemas jurídicos pertenecientes a nuestra tradición; muestras de ello son las massime italianas, las súmulas (vinculantes) brasileñas, ${ }^{113}$ los encabezados de las sentencias españolas y los Leitsätze de las alemanas. ${ }^{114}$ Pero tales resúmenes también son una práctica muy común en los Estados Unidos, a cuyas sentencias suele anteponerse un syllabus, que resume sus puntos torales, los cuales normalmente no forman parte de ella y carecen de efectos vinculantes. ${ }^{115}$

El actual sistema de tesis mexicano surgió como una práctica meramente ilustrativa como las señaladas. Durante la vigencia del Código Federal de Procedimientos Civiles de 1897 comenzaron a adjuntarse "sumarios" a las sentencias publicadas en el Semanario Judicial de la Federación, que describían el caso e indicaban el sentido de la resolución. ${ }^{116}$ Prácticamente desde el inicio de su quinta época, ${ }^{117}$ en el Semanario Judicial de la Federación se publicaban las ejecutorias de la Suprema Corte, precedidas de un "sumario", que brevemente expresaba las cuestiones que abordaban para que se conocieran de manera rápida y sencilla. ${ }^{118}$

El artículo octavo del Reglamento del Departamento de Jurisprudencia de la Suprema Corte emitido durante la vigencia de la Ley de Amparo de

\footnotetext{
112 López Medina, op. cit., nota 30, p. 115, y supra, nota 39.

113 Sobre ambas figuras, véase Saavedra Herrera, op. cit., nota 60, pp. 294 y 295.

114 Aunque no sin críticas, a estas sinopsis de las sentencias del Tribunal Constitucional Federal alemán se les atribuye una "especial importancia". Véase Schlaich, op. cit., nota 107, p. 328 (citando como fuente de aquella aseveración a BVerwGE 73, 263; e idem 77, 258).

115 Garner et al., op. cit., nota 8, p. 150.

116 Saavedra Herrera, op. cit., nota 60, p. 303.

117 Guerrero Lara, Ezequiel, Manual para el manejo del Semanario Judicial de la Federación, México, UNAM, Instituto de Investigaciones Jurídicas, 1982, pp. 34 y 35.

118 Atento lo anterior, porque mostraría su carácter derivado, es muy significativo que en la actualidad se estile publicar las tesis de jurisprudencia vinculante después de su ejecutoria y de sus votos particulares (las ejecutorias de las tesis aisladas no suelen difundirse). Véase por ejemplo: Gaceta del Semanario Judicial de la Federación, lib. 47, octubre de 2017, t. I, disponible en: http://bit.ly/2zKX70y, pp. 69 y ss., y 178 y ss.
} 
1919, dispuso que el "sumario de cada ejecutoria" sería conciso, exacto y claro, y que "fij[aría...] las tesis jurídicas sustentadas" por dicho tribunal. ${ }^{119}$ Por diversos motivos, entre los que destaca el gran número de ejecutorias que debían publicarse, la reproducción de las sentencias fue reduciéndose y omitiéndose en ocasiones, hasta que finalmente —a partir del tomo CXXVI de dicha época- sólo fue posible consultar los sumarios. ${ }^{120}$ Bajo nuevas reglas, en la sexta época jurisprudencial (1957) continuó la práctica de publicar estos extractos previamente a la ejecutoria, pero ya teniendo preferencia la divulgación de aquél mientras que la respectiva sentencia sólo excepcionalmente habría de difundirse; y en la séptima época (1968) se consolidó la práctica, vigente hasta la actualidad, de publicación de la ejecutoria sólo cuando se trate de la que conforma jurisprudencia o la contrariase. ${ }^{121}$

Lo anterior explica el origen de nuestro uso jurisprudencial. Siendo reportadas en el Semanario las decisiones judiciales primordialmente a través de dichas "tesis", no extraña que su empleo haya imperado abrumadoramente en nuestra práctica jurídica. Simplemente, casi siempre, no había otra manera de conocer las decisiones de los jueces y de referirlas.

La difusión de esta práctica hizo surgir un sistema jurisprudencial al que se le reprocha que consista en un "conjunto de criterios judiciales dispersos y fragmentados", "desvincula[dos] de los razonamientos de las sentencias de las que emanan", que principalmente se caracteriza por ser "altamente formalista" y por "incentiva[r] a que pasen a un segundo término las sentencias". ${ }^{122}$ Junto con su "rígida regla de reiteración", se dice que esta práctica hace de nuestro sistema jurisprudencial uno "excesivamente

119 Citado por Saavedra Herrera, op. cit., nota 60, p. 305 (observa este autor que "desde entonces se utilizaba la palabra «tesis» para hacer referencia a los criterios de la propia Suprema Corte").

120 Suprema Corte de Justicia de la Nación, El Semanario Judicial de la Federación y sus épocas. Manual para su consulta, México, 2008, pp. 71-77. Guerrero Lara señala que: 1) la ejecutoria sólo se publicaba completa cuando era "trascendental"; 2) si el sumario no bastaba para explicar el asunto estudiado, se incluía la parte considerativa de la sentencia; y 3) en todos los demás casos, en los cuales el sumario "[era] suficiente para la comprensión del negocio resuelto", se omitía la ejecutoria y se publicaba sólo dicha sinopsis (cfr. op. cit., nota 117, p. 42).

121 Saavedra Herrera, op. cit., nota 60, pp. 312-314.

122 Magaloni, Ana Laura, La Suprema Corte y el obsoleto sistema de jurisprudencia constitucional, documento de trabajo, México, CIDE, núm. 57, 2011, http://bit.ly/1fvuaj3, pp. 2, 18 y 20. También criticando la desvinculación de las circunstancias fácticas que 
formal”, que "pas[a] de ser hermenéutico a burocrático, con una enorme pérdida... de la importancia del derecho judicial en el desarrollo del derecho mexicano". ${ }^{123}$

\section{Precedente, ejecutoria y tesis}

Aunado a otras prácticas criticables (como la inadecuada formulación de las tesis, que con mayores cuidados no resultaría difícil enmendar ${ }^{124}$ ), a lo largo del tiempo el desconocimiento de la lógica del precedente judicial extendió en México la idea de que la jurisprudencia consiste solamente en las tesis "promulgadas" en el Semanario Judicial de la Federación, y que éstas se hallan desvinculadas de la ejecutoria de la que proceden. Pero esta idea es insostenible, y lo era también conforme a la abrogada Ley de Amparo de 1936.

Los artículos 222 a 224 de la vigente legislación de amparo establecen que la jurisprudencia será vinculante por reiteración ${ }^{125}$ "cuando se sustente un mismo criterio en cinco sentencias no interrumpidas por otra en contrario, resueltas en diferentes sesiones", con los requisitos de votación que correspondan para el Pleno y las Salas de la Suprema Corte y para los tribunales colegiados de circuito. ${ }^{126}$ El artículo 218 de la misma ley dispone la elaboración de la tesis respectiva y su publicación en el Semanario. ${ }^{127}$

Sobre la definición de las tesis, y en consecuencia su conformación, ha habido una importante evolución. Aludiré en el último cambio, que es muy significativo.

hicieron surgir una tesis jurisprudencial, véanse González Oropeza, op. cit., nota 64, p. 160; y Saavedra Herrera, op. cit., nota 60, p. 294.

123 López Medina, op. cit., nota 30, pp. 145 y 146.

124 Zertuche García, op. cit., nota 7, pp. 110-111; y González Camarena, Rodrigo, "La creación del precedente en la Suprema Corte de Justicia de la Nación”, en Bernal Pulido, González Camarena y Martínez Verástegui (coords.), op. cit., nota 10, pp. 114-117. Sobre un fenómeno similar en Italia, véase Taruffo, op. cit., nota 40, pp. 200 y 201.

125 Me abocaré a esta figura por su carácter central en el sistema jurisprudencial mexicano. En cierta medida, lo dicho sobre la jurisprudencia por reiteración aplica a la contradicción de tesis. En cambio, la sustitución de jurisprudencia deberá estudiarse junto con la interrupción de la misma, pues ambas corresponden al tema relativo al cambio del precedente, cuyo tratamiento excedería los límites de este trabajo.

126 Artículos 192 y 193 de la abrogada Ley de Amparo de 1936 (texto vigente al 2 de abril de 2013).

127 Artículo 195 idem. 
Los artículos 2o., inciso A, y 4o., inciso A, del acuerdo general 20/2013 del Pleno de la Suprema Corte ${ }^{128}$ establecían lo siguiente sobre la elaboración de las tesis:

La tesis es la expresión por escrito, en forma abstracta, de un criterio jurídico establecido al resolver un caso concreto. En consecuencia, la tesis no es un extracto, una síntesis o un resumen de la sentencia.

[El texto de la tesis deberá] [d]erivar en su integridad de la parte considerativa fundamental de la resolución correspondiente y no contener aspectos que, aun cuando se hayan tenido en cuenta en la discusión del asunto, no formen parte de aquélla. / [Y se] entenderá por parte considerativa fundamental, la concerniente al planteamiento del problema o problemas tratados y las razones de su solución. ${ }^{129}$

Por su parte, ahora los artículos 39 y 41, fracción I, del acuerdo general plenario 17/2019 tratan los mismos aspectos en estos términos:

La tesis hace referencia al criterio jurídico para un caso concreto. La tesis debe ser redactada con estructura de una regla, compuesta por un supuesto de hecho que describa las circunstancias fácticas que constituyen el campo de aplicación de la regla y una consecuencia jurídica donde se establezca la solución normativa. Las cuestiones de hecho y de derecho que no son necesarias para justificar la decisión, en ningún caso deberán incluirse en la tesis. / La tesis no es un extracto, una síntesis o un resumen de la sentencia. ${ }^{130}$

[El texto de la tesis deberá] [d]erivar en su integridad de la parte considerativa de la resolución correspondiente y no contener aspectos que, aun cuando se hayan tenido en cuenta en la discusión del asunto, no formen parte de aquélla.

Con base en la comparación de estas caracterizaciones, puede adelantarse: 1) es un gran acierto que las "circunstancias fácticas" ya sean enfatizadas como elemento integrador del precedente judicial; 2) la aplicación

128 Diario Oficial de la Federación, 12 de diciembre de 2013.

129 Cursivas añadidas. Cfr. título segundo, núm. 1, del acuerdo general 5/2003 del Pleno de la Suprema Corte de Justicia de la Nación (Diario Oficial de la Federación, 8 de abril de 2003). Sobre el origen y evolución de esta definición, véase Saavedra Herrera, op. cit., nota 60, pp. 315-318.

130 Diario Oficial de la Federación, 9 de diciembre de 2019 (cursivas añadidas). 
de este nuevo concepto no debe incurrir en un nuevo formalismo ni excluir la formación de tesis que divulguen criterios puramente normativos pero útiles para la interpretación del ordenamiento, y 3) el éxito de este cambio estribará en la adecuada redacción de las sentencias y de las tesis, y el destierro de hábitos - muy arraigados en México- que las han vuelto habitualmente farragosas y oscuras.

Con todo, de lo anterior se desprende primeramente que las tesis sistematizadas que publica el Semanario deben expresar las rationes decidendi de las ejecutorias de que emanan y no contener obiter dicta, ${ }^{131}$ lo que para comenzar es materialmente un claro guiño a estos conceptos generales relativos al precedente judicial, que últimamente han mencionado los tribunales mexicanos. ${ }^{132} \mathrm{Y}$ enseguida, porque las tesis "emana[n] de las ejecutorias", ${ }^{133}$ que aquéllas no son vinculantes por sí mismas, sino en tanto reflejen con fidelidad el criterio jurídico decisivo que usó el tribunal en sus sentencias.

Sobre lo último, el Pleno de la Suprema Corte de Justicia de la Nación señaló que las tesis "sólo tienen efectos publicitarios", y que su redacción no es indispensable para la obligatoriedad del criterio que expresan; ${ }^{134} \mathrm{en}$

131 Véase supra, § IV.1.A. Sin embargo, especialmente en contradicción de tesis, no resulta extraño ver tesis que sistematizan criterios que carecen de obligatoriedad, por no corresponder al tema cuestionado; pero en no pocas ocasiones - y con la nota de advertencia correspondiente - resultan muy útiles, porque, entre otros, sintetizan prolijos desarrollos jurisprudenciales; un ejemplo de lo anterior es "DEFINITIVIDAD. EXCEPCIONES A ESE PRINCIPIO EN EL JUICIO DE AMPARO INDIRECTO", Segunda Sala, Semanario Judicial de la Federación y su Gaceta, 9a. época, t. XII, julio de 2000, tesis 2a. LVI/2000, p. 156; cfr. supra, notas 109 y 111.

132 Véanse "SOlicitud DE MOdifiCACiÓn DE JURISPRUdENCIA. PROCEDE CUANDO ÉSTA SE UTILICE EN LA CADENA ARGUMENTATIVA DEL CASO CONCRETO, AUN CUANDO NO CONSTITUYA LA RATIO DECIDENDI DEL ASUnTO", Primera Sala, Semanario Judicial de la Federación y su Gaceta, 10a. época, lib. VIII, mayo de 2012, t. 1, tesis 1a. CCXLVI/2011 (9a.), p. 1114; "PRECEDENTES JURISDICCIONALES. PARA DETERMINAR SU APLICACIÓN Y ALCANCE, DEBE ATENDERSE A Su RAZÓn DECISORIA”, Segunda Sala, Gaceta del Semanario Judicial de la Federación, 10a. época, lib. 36, noviembre de 2016, t. II, tesis 2a. CXII/2016 (10a.), p. 1554; y “CONTRADICCIÓN...”, cit., nota 110.

133 “JuRISPRUDENCIA. CONCEPTO, CLASES Y FINES”, Semanario Judicial de la Federación y su Gaceta, 9a. época, t. XVIII, octubre de 2003, tesis IX.10.71 K, p. 1039.

134 “JURISPRUDENCIA. CUANDO SE ESTABLECE POR REITERACIÓN, SE CONSTITUYE POR LO RESUELTO EN CINCO EJECUTORIAS COINCIDENTES NO INTERRUMPIDAS POR OTRA EN CONTRARIO, POR LO QUE LAS OBLIGACIONES DE REDACCIÓN, CONTROL Y DIFUSIÓN SÓLO PRODUCEN EFECTOS PUBlicitARIOS", idem, 9a. época, t. V, mayo de 1997, tesis P. LXIV/97, p. 166. Véase también "JURISPRUDENCIA. CUANDO SE ESTABLECE POR REI- 
tal virtud, tampoco constituyen por sí mismas el precedente judicial ni son necesarias para su existencia. Por eso, para conocer cabalmente verdadero precedente judicial, es decir, el alcance de una tesis jurisprudencial —no siempre tan "claro" como se quisiera ${ }^{135}$ — y su aplicabilidad, "es necesario estudiar las... sentencias que forman la jurisprudencia invocada". ${ }^{136}$

De esta misma opinión ha sido la Primera Sala del máximo tribunal al establecer que en caso de incongruencia entre ellas "debe atenderse a la ejecutoria y no a la tesis redactada", pues "las tesis se redactan en forma sintética a fin de controlarse y difundirse". ${ }^{137}$ Por su parte, la Segunda Sala de la Corte en algún momento opinó que las tesis, sancionadas por un "acto administrativo irrecurrible", habrían de ser aplicadas "en sus términos" y sin que los juzgadores tengan facultad para "cuestionar el carácter,

TERACIÓN, SE CONSTITUYE POR LO RESUELTO EN CINCO EJECUTORIAS COINCIDENTES NO INTERRUMPIDAS POR OTRA EN CONTRARIO, POR LO QUE LA REDACCIÓN, EL CONTROL Y LA DIFUSIÓN DE LAS TESIS CORRESPONDIENTES SÓLO PRODUCEN EFECTOS PUBLICITARIOS”, Segunda Sala, Apéndice al Semanario Judicial de la Federación 1917-2011, t. II, tesis 1719, p. 1953.

135 El caso más grave de incongruencia es el de la tesis P. LXXVII/99 — posición jerárquica de tratados internacionales - y la ejecutoria del amparo en revisión 1475/98 de la que deriva. En esta sentencia, el Pleno de la Suprema Corte expresamente señaló que los tratados que amplían las libertades de los gobernados - en el caso: el Convenio 87 de la OIT - deben considerarse "como constitucionales", pero aquella tesis no reflejó este matiz. Si lo hubiera hecho, México habría contado con un bloque de constitucionalidad doce años antes de la conocida reforma de derechos humanos del 10 de junio de 2011.

136 “JURISPRUDENCIA. EXAMEN DE LAS SENTENCIAS QUE LA CONSTITUYEN. ANALOGÍA. APLICACIÓN INOPERANTE DE LOS PRECEDENTES JUDICIALES POR ESTE CRITERIO”, Semanario Judicial de la Federación, 7a. época, vols. 217-228, sexta parte, p. 364. Véanse también “ANALOGÍA, APLICACIÓN POR, DE TESIS DEL TRIBUNAL EN PLENO”, Pleno, idem, 7a. época, vol. 39, primera parte, p. 14; "CONTRADICCIÓN DE TESIS. CUANDO ES CONFUSA O INCOMPLETA LA TESIS REDACTADA, DEBE ATENDERSE A LA EJECUTORIA RESPECTIVA", Pleno, Semanario Judicial de la Federación y su Gaceta, 9a. época, t. II, octubre de 1995, tesis P. LXXXI/95, p. 81; “CONTRADICCIÓN DE TESIS. CUANDO ES CONFUSA O INCOMPLETA LA TESIS REDACTADA, DEBE ATENDERSE A LA EJECUTORIA RESPECTIVA”, Segunda Sala, idem, 9a. época, t. XIX, abril de 2004, tesis 2a./J. 31/2004, p. 427; y “CONTRADICCIÓN DE TESIS. CUANDO UNA DE LAS TESIS CONTENDIENTES ES CONFUSA O INCOMPLETA DEBE ATENDERSE A LA EJECUTORIA RESPECTIVA", Primera Sala, Apéndice al Semanario Judicial de la Federación 1917-2011, t. II, tesis 1666, p. 1890.

137 “CONTRADICCIÓN DE TESIS. CUANDO LA TESIS REDACTADA CONTIENE ELEMENTOS O SUPUESTOS JURÍDICOS NO ABORDADOS EN LA EJECUTORIA QUE LA ORIGINÓ, DEBE ATENDERSE A ESTA ÚlTIMA PARA VERIFICAR SU EXISTENCIA", Semanario Judicial de la Federación y su Gaceta, 9a. época, t. XXI, abril de 2005, tesis 1a. XXIII/2005, p. 723. 
contenido y proceso de integración de la jurisprudencia"; ${ }^{138}$ aunque años más tarde y con vigor jurisprudencial, apegándose al parecer del Pleno, la misma sala también concluyó que "debe atenderse a [la ejecutoria] y no a la tesis redactada, puesto que el criterio que sustenta el órgano jurisdiccional se encuentra en las consideraciones de la propia resolución". ${ }^{139}$

La legislación vigente corrobora el carácter meramente divulgativo de las tesis, y el papel constitutivo del precedente que tienen las ejecutorias. La parte final del artículo 221 de la Ley de Amparo dispone que de no haberse publicado tesis sistematizada, para acreditar la existencia de un precedente o de un criterio jurisprudencial vinculante "bastará que se acompañen copias certificadas de las resoluciones correspondientes". A mi juicio, esta acreditación también podría hacerse mediante compulsa con el Sistema Integral de Seguimiento de Expedientes (SISE) del Poder Judicial de la Federación. ${ }^{140}$

Esta última disposición legal corrobora que lo realmente decisivo para establecer un precedente judicial es el empleo de la ratio decidendi en el holding de las resoluciones de los tribunales; y si bien ello se podía desprender de la anterior legislación de amparo, ${ }^{141}$ ésta carecía de una dis-

138 “JURISPRUDENCIA. LOS TRIBUNALES COLEGIADOS DE CIRCUITO SÓLO PUEDEN ANALIZAR SI UN CRITERIO JURÍDICO TIENE O NO TAL CARÁCTER, SI NO ESTÁ REDACTADO COMO TESIS CON RUBRO, TEXTO Y DATOS DE IDENTIFICACIÓN", Apéndice al Semanario Judicial de la Federación 1917-2011, t. II, tesis 1725, p. 1959.

139 "CONTRADICCIÓN...", tesis 2a./J. 31/2004, cit., nota 136; véase también "TESIS PUBLICADA. SIN APEGARSE A LO RESUELTO, SU INEXISTENCIA DEBE SER DIFUNDIDA POR RAZONES DE SEgURIDAd JURÍDICA”, Segunda Sala, Apéndice al Semanario Judicial de la Federación 1917-2011, t. II, tesis 1732, p. 1968. Cfr. tesis P. LXIV/97, cit., nota 134; y "Jurisprudencia. Debe modificarse la de una Sala si el Pleno sustenta una TESIS CONTRARIA, AUNQUE SEA AISLADA", Segunda Sala, Semanario Judicial de la Federación y su Gaceta, 9a. época, t. XXV, abril de 2007, tesis 2a. XXII/2007, p. 561.

140 Por todos véase "Hechos NOTORIOS. TIENEN ESE CARÁCTER LAS VERSIONES ELECTRÓNICAS DE LAS SENTENCIAS ALMACENADAS Y CAPTURADAS EN EL SISTEMA INTEGRAL DE Seguimiento de ExPedientes (SISE)", Pleno, Gaceta del Semanario Judicial de la Federación, 10a. época, lib. 55, junio de 2018, t. I, tesis P./J. 16/2018 (10a.), p. 10.

141 Aparte de las señaladas, así lo indicó la Suprema Corte en otras ocasiones; e. $g$. "JURISPRUDENCIA. NO ES OBJETO DE DECLARACIÓN ABSTRACTA A PETICIÓN ESPECIAL, SINO QUE SE FORMA Y TOMA EN CUENTA AL SUSTENTARSE EN EL NÚMERO DE EJECUTORIAS CON LOS REQUISITOS LEGALES QUE LA DETERMINAN... la jurisprudencia... nace del simple hecho espontáneo de que se reúna el número de precedentes que exige la ley, con los requisitos que la misma fija...", Segunda Sala, Semanario Judicial de la Federación, 7a. época, vol. 18 , tercera parte, p. 85 . 
posición tan clara como el artículo 221, in fine, de la vigente. ${ }^{142}$ Así, hoy resulta indudable que la existencia de la jurisprudencia o de un precedente no depende de un acto formal de elaboración de la respectiva tesis ni de su difusión oficial, que se tratarían de actos meramente declarativos a efecto de "mera" divulgación, y no de uno constitutivo. ${ }^{143}$ Desde luego, tampoco habría impedimento para que los operadores jurídicos acudan a la resolución, y no a la tesis, a efecto de invocar con cabal precisión un criterio judicial. ${ }^{144}$

A lo anterior no se opone que desde diciembre de 2013 el Semanario Judicial de la Federación cada viernes publica tesis y ejecutorias, y que los criterios jurisprudenciales que éstas contienen deben considerarse de "aplicación obligatoria" a partir del día (lunes) hábil siguiente, conforme al punto séptimo del acuerdo general plenario 16/2019. Por el contrario, el último párrafo de la misma disposición confirma la primacía de la ejecutoria y de su mera existencia, al establecer que la obligatoriedad de las tesis se dará sin perjuicio de los artículos 221, parte final, de la Ley de Amparo, y 43, de la Ley Reglamentaria del Artículo 105 Constitucional. ${ }^{145}$ Así, la comprobación del respectivo precedente mediante los medios oficialmente reconocidos al efecto (copia certificada, versión electrónica del SISE, remisión electrónica oficial ${ }^{146}$ o publicación en el Diario Oficial de la Federación), es una excepción a la regla general de que carecen de efecto vinculante los precedentes pendientes de divulgación en el Semanario.

Habiéndose acreditado la existencia de las correspondientes ejecutorias y que contienen cierto precedente, el juzgador ante quien el mismo se invoque

142 Véase en general Rosales Guerrero, op. cit., nota 72, pp. 220-232.

143 En los Estados Unidos hay un "interesante desacuerdo" sobre si, las consideraciones de las sentencias que no han sido publicadas oficialmente constituyen precedentes, y por ende si tienen fuerza vinculante; la respuesta tradicional ha sido proscribir su invocación, pero esta regla se ha "suavizado considerablemente"; cfr. Garner et al., op. cit., nota 8, pp. 142-149. Entre los precedentes relativos a esta polémica, se inclina implícitamente en sentido afirmativo Anastasoff v. United States, 223 F.3d 898, 899 (pp. 4 y ss.) (8th Cir. 2000) (las páginas entre paréntesis se refieren a su versión electrónica en http://bit. ly/2wPblYV), invalidada por improcedencia (moot) por el tribunal pleno (en banc) en 235 F.3d 1054 (8th Cir. 2000).

144 Camarena González, op. cit., nota 124, p. 117.

145 Punto séptimo del acuerdo general 19/2013 del Pleno de la Suprema Corte de Justicia de la Nación (Diario Oficial de la Federación, 29 de noviembre de 2013).

146 Conforme al punto quinto del acuerdo general plenario 17/2019, y artículos 16 y 17 del acuerdo general plenario 20/2013 (Diario Oficial de la Federación, 12 de diciembre de 2013). 
deberá reconocerle el efecto vinculante que le corresponda, aunque a su respecto no se hubiera redactado una tesis sistematizada, o que ésta o las ejecutorias relativas tampoco se hubieran publicado en el Semanario. ${ }^{147}$ Lo que acaso variaría en estas condiciones sería la responsabilidad del juzgador ${ }^{148} \mathrm{y}$ la de las partes ${ }^{149}$ que actuaran contra un precedente cuya existencia ignoraban, y cuya difusión en el Semanario haría inexcusable su desconocimiento. De otra manera, el artículo 221, in fine, de la Ley de Amparo, carecería de sentido por inoperante, y vaciarlo de contenido es una opción interpretativa inadmisible, especialmente porque los acuerdos generales plenarios no pueden contravenir las disposiciones legales que reglamentan. ${ }^{150}$

\section{Tradición y evolución}

No obstante que la propia Ley de Amparo y en ocasiones la Suprema Corte han acercado el sistema jurisprudencial de nuestro país a una "teoría general” del precedente, aún falta camino por recorrer para que en México percibamos habitualmente y con nitidez la verdadera naturaleza y la dinámica jurídica que los jueces crean con sus decisiones. Las anteriores notas llevan a valorar la auténtica jurisprudencia de nuestros tribunales, es decir, la contenida en sus resoluciones, y a reducir la importancia de las tesis sistematizadas a una mera herramienta de difusión, aun con independencia de su publicación en el Semanario u otros medios oficiales. ${ }^{151}$

147 “JuRISPRUdENCIA DE LA SUPREMA CORTE DE JUSTICIA DE LA NACIÓN. LA OBLigATORIEDAD DE SU APLICACIÓN, EN TÉRMINOS DEL ARTÍCULO 217 DE LA LEY DE AMPARO, SURGE A PARTIR DE SU PUBLICACIÓN EN EL SEMANARIO JUdiCIAL DE LA FEDERACIÓN", Segunda Sala, Gaceta del Semanario Judicial de la Federación, 10a. época, lib. 25, diciembre de 2015, t. I, tesis 2a./J. 139/2015 (10a.), p. 391.

148 “JURISPRUDENCIA. LA OBLIGATORIEDAD CONSTITUCIONAL DE LA SUSTENTADA POR EL Poder Judicial de LA FEDERACIÓN, EXIGE DE LOS JUZGADORES ANÁlisis Y SEGUIMIENTO PERMANENTES DE LOS MEDIOS INFORMATIVOS QUE LA DIFUNDEN", Segunda Sala, Semanario Judicial de la Federación y su Gaceta, 9a. época, t. XII, agosto de 2000, tesis 2a. CV/2000, p. 364.

149 "RECLAMACIÓN...", cit., nota 46.

150 Ezquiaga Ganuzas, op. cit., nota 58, pp. 271, y 277 y 278; y Sánchez Gil, Rubén, "Los acuerdos generales plenarios de la Suprema Corte de Justicia de la Nación", manuscrito inédito, 10 de diciembre de 2019 (archivo del autor), en Cossío Díaz, José Ramón y Astudillo, César (coords.), Organización y funcionamiento de la Suprema Corte de Justicia de la Nación (en preparación), § III.3.

151 “ACCIÓN DE INCONSTITUCIONALIDAD. Si EN ELLA SE DECLARA LA INVALIDEZ DE NORMAS GENERALES, LOS ÓRGANOS JURISDICCIONALES DEBEN APLICAR ESE CRITERIO, 
Sin embargo, el sistema mexicano de tesis jurisprudenciales es compatible con una visión más amplia del precedente judicial, y más tradicional desde el punto de vista del common law. Incluso, la primacía de la sentencia en los Estados Unidos no es tan homogénea como creemos en México.

La mayoría de las jurisdicciones están por negar a los syllabi todo efecto vinculante, y por considerarlos un elemento ajeno a la resolución. ${ }^{152}$ En una ya clásica sentencia, por lo que a ella respecta, la Suprema Corte de ese país ha señalado enfáticamente que el encabezado es "labor de quien reporta", no del tribunal, y que se prepara sólo para la "conveniencia" de quien desea informarse de su contenido. ${ }^{153}$ Pero algunas entidades federativas norteamericanas han adoptado la posición de que dicha sinopsis "debería mantener alguna presunta apariencia (some semblance) de precedente" (cursivas originales suprimidas): 1) Kansas atribuye efecto vinculante a los syllabi, y considera que expresan holdings; 2) Minnesota tiene una regulación similar; 3 ) en Virginia occidental, el sumario establece los puntos jurídicos importantes de la decisión, y ambos tienen valor de precedente; los litigantes tienen la libertad de invocar cualquiera, y 4) en Ohio, el "ejemplo más extremo", la ley exige que todo punto jurídico decidido se encuentre en un syllabus, y sólo éste, "y no la sentencia (opinion) en su integridad" tiene carácter de precedente.

Es innegable la gran utilidad que brindan las tesis mexicanas al facilitar la referencia jurisprudencial en nuestra práctica, frente a las desventajas —a veces exageradas — que se les atribuyen. ${ }^{154}$ Jueces, litigantes y académicos empleamos habitualmente las tesis porque facilitan el manejo de los precedentes por permitir identificarlos y localizarlos en función de palabras o frases clave de sus "rubros", en especial a partir de su sistemati-

AUN CUANDO NO SE HAYA PUBLICADO TESIS DE JURISPRUDENCIA", Segunda Sala, Apéndice al Semanario Judicial de la Federación 1917-2011, t. II, tesis 74, p. 4494; y el artículo cuarto, fracción I, inciso D), del Acuerdo General 5/2013 del Pleno de la Suprema Corte de Justicia de la Nación (Diario Oficial de la Federación, 21 de mayo de 2013).

152 Para lo sucesivo en este párrafo, véase Garner et al., op. cit., nota 8, pp. 150-152.

153 United States v. Detroit Timber \& Lumber Co., 200 U.S. 321, 337 (1906) (reconoce, no obstante, que "una regla diferente, es verdad, se prescribe por ley en algunos estados"). Véase también Suprema Corte de los Estados Unidos, Information About Opinions, disponible en: http://bit.ly/2YEvvUm (12 de diciembre de 2019).

154 Camarena González, op. cit., nota 124, p. 116 (afirman que hay tesis que "sí son fieles a la litis y los hechos del caso" [cursivas en el original], o a cuyo respecto "no es difícil inferir una [regla específica] a partir de la tesis"). 
zación informática. ${ }^{155}$ Este sistema es particularmente eficiente cuando en una sola ejecutoria se sientan diversos criterios, pues permite identificar con claridad cada uno de ellos, e incluso sus distintos matices. ${ }^{156}$

Por estos motivos, me parece desafortunado que desde 2016 la Suprema Corte ya no expida tesis derivadas de las ejecutorias que dicta en controversias constitucionales y acciones de inconstitucionalidad. ${ }^{157}$ Con el aval de la Ley de Amparo, ${ }^{158}$ estos elementos divulgativos garantizaban el conocimiento de los criterios sentados también para esta clase de asuntos, sin perjuicio de que el efecto vinculante de sus precedentes derive de la correspondiente ejecutoria. ${ }^{159}$ Asimismo, la redacción de tesis - concebidas como meros instrumentos de difusión, según vimos - tampoco se contrapone a la existencia del sistema de precedentes en controversias constitucionales y en acciones de inconstitucionalidad basado en sus ejecutorias; de hecho, los "rubros temáticos" con que este sistema identifica los criterios jurídicos establecidos en tales resoluciones cumplen la función orientadora que originó nuestro sistema de tesis, y pueden dar lugar a

155 Utilidad que reconoce el artículo 3o., apartados A y C, del Acuerdo General 20/2013 del Pleno de la Suprema Corte de Justicia de la Nación, al prescribir que facilitar la localización de las tesis es uno de los propósitos que debe orientar la redacción de sus rubros.

156 Un buen ejemplo es el amparo directo 35/2014 de la Primera Sala del Máximo Tribunal —el caso Bullying_, del que se desprendieron 33 tesis jurisprudenciales.

157 Desde la modificación del punto tercero del acuerdo general plenario 19/2013 a través del instrumento normativo publicado en el Diario Oficial de la Federación del 18 de abril de 2016, que simplemente eliminó toda alusión a la publicación de las "tesis respectivas" que derivasen de las ejecutorias de dichos procesos. La misma posición adopta el punto tercero del acuerdo general plenario 16/2019, que significativamente omite mencionar las "respectivas tesis jurisprudenciales" procedentes de controversias constitucionales, acciones de inconstitucionalidad y — ahora también — declaratorias generales de inconstitucionalidad, que en cambio sí menciona respecto de la jurisprudencia por reiteración y otras especies. Véase en general Suprema Corte de Justicia de la Nación, El Semanario Judicial de la Federación. Su evolución a un sistema digital de compilación y difusión, México, 2016, pp. 69, 70 y 153-157.

158 Véase el artículo 177 de la Ley Orgánica del Poder Judicial de la Federación.

159 Por mayoría de razón, cfr. "TRIBUNALES COLEGIADOS DE CIRCUITO. AUNQUE LAS CONSIDERACIONES SOBRE CONSTITUCIONALIDAD DE LEYES QUE EFECTÚAN EN LOS JUICIOS DE AMPARO DIRECTO, NO SON APTAS PARA INTEGRAR JURISPRUDENCIA, RESULTA ÚTIL LA PUBLICACIÓN DE LOS CRITERIOS", Pleno, Semanario Judicial de la Federación y su Gaceta, 9a. época, t. VIII, septiembre de 1998, tesis P. LX/98, p. 56. 
la elaboración de éstas en aras de controlar y sistematizar los precedentes sentados en dichos procesos constitucionales. ${ }^{160}$

Es cierto que nuestro sistema de formulación de tesis es perfectible, pero a mi juicio no implicaría mayor esfuerzo que atender a su adecuada redacción para que refleje con mayor claridad los hechos del caso y la ratio decidendi a que corresponda. Y también lo mismo podría decirse de la claridad que debe tener la formulación de las resoluciones judiciales para que su razonamiento pueda fungir como precedente, por ser preciso, diáfano y nítido en cuanto a sus premisas — jurídicas y fácticas - y a su razonamiento. ${ }^{161}$

Advertir que las tesis consisten de un mero reflejo del criterio de una decisión jurídica que se dio en función de determinadas circunstancias que constituyeron uno o varios casos particulares permitirá tener un manejo más adecuado de nuestros precedentes mediante técnicas de manejo jurisprudencial - aplicables de modo general, aunque originadas en el common law-, a las cuales ya se ha referido la Suprema Corte de Justicia de la Nación. ${ }^{162}$ Para que nuestro sistema jurisprudencial funcione mejor, antes que grandes cambios se requiere una diferente perspectiva sobre el precedente judicial que permita algunos ajustes en su comprensión y en su operación. Para llegar a buen puerto, la aplicación jurisprudencial requiere "una determinada manera de leer y [de] escribir sentencias". ${ }^{163}$

El primero de dichos ajustes sería asumir de modo general que las tesis gozan de una presunción iuris tantum de expresar un precedente, y suponer que formulan correctamente la ratio decidendi de la ejecutoria de que emanan, y se relaciona con una mayor precisión en la redacción de las tesis y las ejecutorias a que corresponden. Aunque por esta misma calidad

160 Supra, nota 116; punto cuarto, párrafo segundo, del acuerdo general plenario 16/2019; y punto cuarto, último párrafo, y décimo, del acuerdo general plenario 19/2013 (antes y después de su modificación por el instrumento normativo referido supra, nota 157).

161 Ramírez Alvarado, Julia, ponencia en la mesa panel El Precedente Judicial en México: Retos, Problemas y Debates, Mérida, Casa de la Cultura Jurídica de la Suprema Corte de Justicia de la Nación, 27 de junio de 2019.

162 Véase por ejemplo "PreCEDENTES...", cit., nota 84 (reconoce la técnica de la "distinción" [distinguishing] que aparta el caso actual de la regla establecida en el precedente).

163 Ferreres Comella, op. cit., nota 16, pp. 76 y 77. 
secundaria y por su propósito meramente declarativo y divulgativo, ${ }^{164}$ habríamos de admitir que la ejecutoria correspondiente debe prevalecer a todos los efectos, sea para precisar el significado de la tesis, esclarecer las condiciones de su aplicación o aun determinar el verdadero sentido del criterio jurídico del tribunal. ${ }^{165}$ Entendido así nuestro sistema, el ordenamiento mexicano podría ajustarse a una teoría general del precedente - cuyos aspectos fundamentales ha elaborado el common law - y a la práctica jurisprudencial de otros países pertenecientes a nuestra tradición jurídica, sin abandonar sus peculiaridades tradicionales.

\section{Múltiples efectos vinculantes}

\section{A. La autoridad del precedente vertical}

El empleo del precedente en el razonamiento jurídico es una de las especies del argumento de autoridad o ab exemplo, que Giovanni Tarello define como aquel "por el que a un enunciado normativo le es atribuido aquel significado que ya le había sido atribuido por alguien, y por ese solo hecho". ${ }^{166}$ El precedente "representa un prototipo, un modelo para futuras resoluciones que se refieren a casos similares"; 167 pero no solamente es un "buen ejemplo" — y aun podría ser malo-, sino que es uno dotado de la "autoridad" del órgano judicial que generó la regla que expresa. ${ }^{168}$

Por su "papel central en la explicación del concepto de precedente" y afines, como veremos en secciones posteriores, hay que distinguir claramente las acepciones del término "autoridad". En nuestro contexto, este término alude primordialmente a: 1) el prestigio o crédito reconocido a una persona $u$ órgano por su competencia o calidad, que en adelante calificaré de "material", y 2) la potestad para ordenar o mandar sobre otros, que sucesivamente designaré como "formal". ${ }^{69}$

164 Reconocido desde años atrás, incluso por la Suprema Corte. Véanse Zertuche García, op. cit., nota 7, pp. 131-133, y "JURISPRUDENCIA. NO ES...”, cit., nota 141.

165 Camarena González, op. cit., nota 124, pp. 117 y 118.

166 Ezquiaga Ganuzas, op. cit., nota 58, pp. 325 y 327 (de Tarello este autor cita L'interpretazione della legge, Milán, 1980, p. 372).

167 Larenz, op. cit., nota 47, p. 429.

168 Gómora Juárez, op. cit., nota 10, pp. 104, 105, 114, 115 y 133.

169 Ibidem, pp. 40 y 41. 
El precedente vertical se relaciona con ambas especies de autoridad. En cambio, la autoridad formal señalada carece de relevancia para el llamado precedente "horizontal", porque los tribunales homólogos generalmente carecen de potestad para imponerse uno a otro; aunque es posible que algunas consideraciones sobre el vertical puedan aplicar a esta clase por efecto de su relación con la autoridad materialmente entendida. Y por el contrario, el "autoprecedente" no implica vinculación alguna, sino que más bien consiste en un criterio de racionalidad, que nada tiene que ver con el concepto de "autoridad", y que más bien se relaciona con el principio de universabilidad. ${ }^{170}$ Por estos motivos, en lo sucesivo me ocuparé exclusivamente del arquetípico precedente vertical.

Evidentemente, caracterizar el precedente como un "ejemplo" lo relaciona con la autoridad material, en tanto que hacerlo consistir en una "regla prescriptiva" lo vincula con la formal. Los sendos puntos de vista que resultan de entender la "autoridad" del precedente en uno y en otro sentido permiten ver con claridad su naturaleza y diseccionarla con más precisión.

La ejemplaridad del precedente es la cualidad que le permite proyectarse y servir de modelo para solucionar casos futuros que son análogos a aquel en que se estableció. ${ }^{171}$ Pero esta cualidad nos obliga a ir más allá del argumento analógico, y a cuestionarnos por qué se toma como "norma de referencia" el criterio de determinado tribunal, y no el de otro o cualquier fuente diversa. La analogía tiene una estructura formal - la cual estriba en la semejanza y la búsqueda de una ratio (legis o decidendi, según corresponda) - que en manera alguna indica la norma sustantiva que le sirve de base. ${ }^{172}$ Sin embargo, la ejemplaridad no se agota en la mera analogía, sino que emplea ésta como vehículo para la emulación de acciones, y en especial de las actitudes, de un sujeto al que se atribuye "autoridad material" por su calidad "superior". ${ }^{173}$

Partiendo del supuesto de que los profesionales más capaces y experimentados ocupan las posiciones más altas de la organización judicial, es de esperarse que cuanto mayor altura tenga un tribunal en esta estructura, tanto mayor sería la "calidad" de sus respuestas y su "autoridad material";

${ }^{170}$ Gascón Abellán, op. cit., nota 43, pp. 212 y 214-218.

171 Gómora Juárez, op. cit., nota 10, pp. 103 y 104.

172 Ezquiaga Ganuzas, op. cit., nota 58, pp. 15-19.

173 Amaya, Amalia, "Ejemplaridad y derecho", en Bernal Pulido, González Camarena y Martínez Verástegui (coords.), op. cit., nota 10, pp. 58-62 y 66. 
y que cuanto mayor sea el número de estratos judiciales, tanto mayor será el número de los grados de la escala de calidad y autoridad judiciales. Este factor cuantitativo apunta a la existencia de tantos niveles de jerarquía jurisprudencial como estratos haya en una determinada organización judicial.

Sin embargo, aunque fuera "suprema" la autoridad material de un órgano jurisdiccional, sus opiniones carecerían propiamente de la calidad de "precedentes" de no ser por su autoridad formal. Es decir, la potestad jurídica de calificar y determinar la conducta de tribunales de inferior jerarquía es decisiva para que un criterio judicial sea un "precedente". Desde luego, ambas especies de autoridad pueden coexistir, pero sólo la formal es constitutiva del "precedente", en tanto que la material sólo resulta deseable y ha de presumirse, ${ }^{174}$ pero sin ser materialmente necesaria para que se actualice este concepto. A este respecto, cobra plena aplicación el célebre aforismo del justice Robert H. Jackson, que describe el papel del tribunal supremo norteamericano: "No tenemos la última palabra porque seamos infalibles, sino que somos infalibles sólo porque tenemos la última palabra". ${ }^{175}$

El precedente goza de una autoridad "práctica", no "teórica", pues provee "razones para la acción", impone "razones para decidir", con independencia de que realmente se esté o no de acuerdo con su sentido. ${ }^{176}$ Por ello, para que en su virtud surja un deber jurídico puede prescindirse de la adhesión ideológica del operador jurídico al contenido del precedente. De lo contrario, no podría entenderse la posibilidad de que simultáneamente se critique pero deba seguirse el precedente ${ }^{177}$ ni que pueda darse — de un modo vital para la democracia ${ }^{178}$ — una amplia discusión en el seno de la sociedad sobre tópicos que ya han sido resueltos jurisprudencialmente. ${ }^{179}$

174 Caminker, op. cit., nota 44, p. 868.

175 Brown v. Allen, 344 U.S. 443, 540 (1953) (concurrente): "We are not final because we are infallible, but we are infallible only because we are final".

176 Gómora Juárez, op. cit., nota 10, pp. 41-43, y Laporta, op. cit., nota 27, pp. 36 y 37.

177 Garner et al., op. cit., nota 8, p. 32.

178 Post, Robert y Siegel, Reva, "Roe rage: Democratic constitutionalism and backlash", Harvard Civil Rights-Civil Liberties Law Review, Cambridge, Universidad de Harvard, Escuela de Derecho, vol. 42, núm. 2, verano de 2007, disponible en: http://bit. ly/2xS5Qem, pp. 379 y 389-390.

179 Gómora Juárez, op. cit., nota 10, pp. 43, 44 y 110-112. 
El precedente goza claramente de autoridad formal cuando la disposiciones legales - como las mexicanas - explícitamente otorgan a las opiniones judiciales la potestad de guiar la conducta de otros tribunales. Pero primordialmente por efecto de la organización judicial, dicha especie de autoridad también tendría lugar incluso si tales prescripciones no existieran. ${ }^{180}$

En términos generales, ${ }^{181}$ únicamente a los tribunales terminales — que por definición tienen una jerarquía superior a otros - se les atribuye la capacidad de sentar precedentes, por la simple y sencilla razón de que sus decisiones tienen carácter definitivo, son irrevocables y no pueden ser sustituidas ni superadas por las de otro órgano; aunque pueden existir tribunales intermedios cuyos criterios tienen "meno[r] valor como precedentes". ${ }^{182}$ Por la calidad que se supone en sus integrantes, las decisiones de los tribunales superiores gozan de la presunción de ser "correctas", y en consecuencia sus precedentes controlan - para usar la terminología norteamericana- las decisiones de los inferiores. Actuando conforme a la pretensión de corrección inherente al sistema jurídico, ${ }^{183}$ éstos han de preferir aquella respuesta "correcta" a cualquier otra; si no lo hicieran, resolverían "incorrectamente", y ésta es una opción sencillamente inadmisible. El vigor del precedente como respuesta presuntamente "correcta" se mantiene incluso ante su aparente equivocación (¿según quién?), o ante la posibilidad de que el tribunal que lo estableció variase de opinión; cambiar el sentido

180 Supra, nota 61.

181 Gómora Juárez, op. cit., nota 10, pp. 74 y 82-84.

182 Garner et al., op. cit., nota 8, p. 255. Una peculiaridad del sistema mexicano es la jurisprudencia sobre inconstitucionalidad de normas generales establecida por tribunales colegiados. En amparo directo, esta posibilidad parece estar excluida (véase "TRIBUNALES...", cit., nota 159); pero en virtud de la autoridad delegada en amparos en revisión contra leyes locales y otras normas generales que a dichos tribunales han otorgado los acuerdos plenarios 5/2001 y 5/2013, fungen como órganos terminales capaces de establecer jurisprudencia (por todos véase "SUPLENCIA DE LA QUEJA DEFICIENTE PREVISTA EN EL ARTíCULO 76 BIS, FRACCIÓN I, DE LA LEY DE AMPARO. PROCEDE CUANDO EN EL AMPARO INDIRECTO SE SEÑALEN DIRECTAMENTE COMO ACTO RECLAMADO UNA LEY DECLARADA INCONSTITUCIONAL POR JURISPRUDENCIA DE UN TRIBUNAL COLEGIADO DE CIRCUITO Y COMO RESPONSABLES SUS ÓRGANOS EMISORES", Semanario Judicial de la Federación y su Gaceta, 10a. época, lib. XI, agosto de 2012, t. 2, tesis IV.2o.A.14 K (10a.), p. 1994). Pero aun en estos casos, si ejerciera su facultad de atracción, la Suprema Corte podría superar el precedente de un tribunal colegiado; mas es claro que ésta sería una situación excepcional.

183 Sobre este concepto, véase Alexy, op. cit., nota 33, pp. 264-268, y 428 y 429. 
del precedente judicial es prerrogativa del tribunal superior que lo estableció. ${ }^{184}$

Esta conformidad con la pretensión de corrección del sistema jurídico conlleva satisfacer otros fines cuya realización impulsa principalmente el precedente judicial: seguridad jurídica e igualdad en la aplicación de la ley. ${ }^{185}$ Impedir que los tribunales inferiores se aparten de la respuesta "correcta" que éste representa contribuye a la predictibilidad y la uniformidad del derecho en todas las fases procesales, reforzando su eficacia y evitando la arbitrariedad de los juzgadores. En seguida, favorece la igualdad en la aplicación de la ley, pues asimismo evitará que casos que ameriten la misma respuesta jurídica sean tratados de modo diferente. Sin embargo, el punto clave de la autoridad del precedente y para atribuir esta calidad a un criterio judicial es el siguiente: no se trata de garantizar cualquier predictibilidad e igualdad en la aplicación jurídica, sino que estas características se relacionen con una opinión sobre la cual hay una razonable expectativa de que se ajuste a la del tribunal que tendría la decisión final del caso. ${ }^{186}$

El stare decisis tiende a asegurar que todos los casos se resuelvan siempre de acuerdo con el precedente, es decir, la presuntamente "correcta" opinión del tribunal que tendría la última palabra a su respecto. Y esto justifica que el precedente siempre tenga autoridad formal para ser considerado por los tribunales inferiores al momento de decidir; a la inversa, ello también explica que éstos no se hallen vinculados en modo alguno a las opiniones de tribunales que no ejerzan control sobre ellos. Estos dos sentidos son la base de lo expuesto en las siguientes secciones.

De esta manera, el concepto de "autoridad" es clave para ver con nuevos ojos el sistema jurisprudencial mexicano, y revisar características suyas que sin mayor cuestionamiento hemos dado por firmemente sentadas, cuando en realidad deberíamos reflexionar por qué las concebimos como lo hacemos, para verificar si las llevamos a la práctica como se debería. ${ }^{187}$

${ }^{184}$ Rodriguez de Quijas v. Shearson/American Express, Inc., 490 U.S. 477, 484 (1989). Véase también Garner et al., op. cit., nota 8, pp. 28-30.

185 Pérez Portilla, op. cit., nota 50, pp. 73 y 74.

186 “JURISPRUDENCIA ESTABLECIDA POR UN PLENO DE CIRCUITO. ES OBLIGATORIA TANTO PARA LOS TRIBUNALES COLEGIADOS QUE SE UBIQUEN DENTRO DE ESE CIRCUITO COMO PARA LOS AUXILIARES QUE LOS APOYEN EN EL DICTADO DE SUS RESOLUCIONES, INDEPENDIENTEMENTE DE LA REGIÓN A LA QUE ÉSTOS PERTENEZCAN”, Gaceta del Semanario Judicial de la Federación, 10a. época, lib. 26, enero de 2016, t. IV, tesis (IV Región)2o.8 L (10a.), p. 3356.

187 Caminker, loc. cit., nota 44. 


\section{B. Efecto vinculante y escala de precedentes}

Otro de los postulados que caracterizan la práctica mexicana es la convicción de que existe una categórica separación entre los criterios jurisprudenciales stricto sensu, de aplicación inexorable, y los criterios "aislados", que carecerían absolutamente de efecto vinculante, y cuya importancia - en el mejor de los casos - es meramente académica y especulativa. En la actualidad, esta dicotomía es difícilmente sostenible. ${ }^{188}$

Expresando "razones para decidir" basadas en la autoridad formal y material que lo establece, todo precedente judicial siempre debe ser tomado en cuenta al decidir, aunque ello no implica que su sentido necesariamente haya de prevalecer. ${ }^{189}$ Siendo aplicable para adoptar una decisión, a un precedente debería dársele efecto, con el fin de garantizar los valores jurídicos que representa — seguridad, igualdad, etcétera —; pero existiendo en términos generales la posibilidad de que quien desee apartase de él, para hacerlo válidamente, cumpla con la carga de argumentar que resulta mejor alejarse de su sentido, y es una cuestión diferente que un determinado ordenamiento prevea formalmente la obligación de cumplir con dicha carga. ${ }^{190}$

Lo anterior lleva a asumir que todos los precedentes siempre tienen, con mayor o menor intensidad, un efecto prima facie vinculante, ${ }^{191}$ que en el curso argumentativo podría ser vencido con dificultad o con facilidad, y que sólo de modo excepcional dicho efecto haría que el criterio judicial prevalezca absolutamente. De esta manera, habría que reflexionar de nuevo sobre los puntos de vista tradicionales relativos a: 1) la categórica separación entre precedentes inexorablemente "vinculantes", y los meramente persuasivos u "orientadores", y 2) la impresión de que éstos son una simple guía que potestativamente puede considerarse en el razonamiento jurídico. ${ }^{192}$ Como detallaré en seguida, aquellas proposiciones en realidad se hallan bastante difundidas.

188 Xiol Ríos, op. cit., nota 54, p. 105. Véase también López Medina, op. cit., nota 30, pp. 206 y 207.

189 Laporta, op. cit., nota 27, p. 37.

190 Alexy, op. cit., nota 33, p. 339.

191 Camarena González, op. cit., nota 124, p. 118.

192 Véase por ejemplo "TESIS AISLADAS. LAS EMITIDAS POR LA SUPREMA CORTE DE JUSTICIA DE LA NACIÓN TIENEN CARÁCTER ORIENTADOR, NO GENERAN DERECHOS NI SON SUSCEPTIBLES DEL EJERCICIO DE IRRETROACTIVIDAD”, Segunda Sala, Gaceta del Semanario Judicial de la Federación, 10a. época, lib. 38, enero de 2017, t. I, tesis 2a./J. 195/2016 (10a.), p. 778. 
La mayoría de los sistemas jurídicos, incluso connotados integrantes de la tradición romanista, no trazan una línea tajante entre los precedentes judiciales para separarlos en unos absolutamente vinculantes y otros que carecen de todo efecto. ${ }^{193}$ Más bien, en términos generales, antes que de la "validez" o de la "vigencia" de un precedente, debe hablarse de su "solidez", pues tendrá mayor o menor "peso normativo" según la diferente proporción con que satisfaga ciertas características definidas por el sistema jurídico al que pertenezca.

Generalmente, los sistemas jurídicos no tratan a los precedentes de modo categórico, como si su obligatoriedad fuera cuestión de "todo o nada". En realidad, les atribuyen distintos niveles de vigor, ${ }^{194}$ que van desde reconocerles formalmente un muy fuerte efecto vinculante hasta admitir que tienen una "eficacia normativa persuasiva", que puede superarse con mayor o menor facilidad, pero no ser soslayada. ${ }^{195}$

Algunos autores han formulado escalas con una pluralidad de grados de efecto vinculante de los precedentes judiciales. ${ }^{196}$ Por su precisión, la que elaboró Taruffo ${ }^{197}$ me parece la más atendible. Expondré a continuación la propuesta del mencionado procesalista italiano con ejemplos tomados del derecho mexicano (no todos vigentes, pero sí ilustrativos), y señalaré el calificativo que correspondería al precedente según las cualidades de la vinculación que genere:

1) Absolutamente vinculante. Existe obligación "absoluta y sin excepciones" de seguir el precedente. Tal es hoy el caso de la jurisprudencia vinculante de la Suprema Corte de Justicia de la Nación, que no admite examen de su inconvencionalidad — la cual podría basarse en su contraste con la jurisprudencia interamericana-. ${ }^{198}$

193 Véase en general MacCormick y Summers, op. cit., nota 5, pp. 505 y 506.

194 Gascón Abellán, op. cit., nota 43, p. 212 (habla de un continuum de la eficacia vinculante del precedente conforme a "la mayor o menor fuerza que se atribuya a las razones para seguirlos").

195 "Mientras que la jurisprudencia vinculante (binding caselaw) tiene que seguirse, la persuasiva «no obliga a un tribunal, pero no obstante es acreedora de respeto y de cuidadosa consideración»", Garner et al., op. cit., nota 8, p. 164 (cursivas añadidas; cita Black's Law Dictionary, p. 1367).

196 Véanse por ejemplo MacCormick y Summers (eds.), op. cit., nota 5, pp. 516-518; y Orozco Muñoz, op. cit., nota 34, pp. 191 y 192.

197 Op. cit., nota 40, pp. 204 y 205.

198 “Jurisprudencia de la Suprema Corte de Justicia de la NACión. No ES SusCEPTIBLE DE SOMETERSE A CONTROL DE CONSTITUCIONALIDAD Y/O CONVENCIONALIDAD 
2) Meramente vinculante (binding). El precedente debe seguirse "salvo excepciones previstas". En nuestro derecho doméstico, antes de la resolución mencionada en el inciso anterior, tal era la situación de los criterios de la Corte Interamericana y de los mexicanos que estableció la contradicción de tesis 293/2011: en principio, ambos precedentes exigían igual aplicación, pero se especificaba que en caso de oposición prevalecía el más favorable al derecho humano con que se relacionen. ${ }^{199}$

3) "Máxima" venciblemente vinculante (defeasibly binding). De estos precedentes "el juez sucesivo pued[e] apartarse, siempre que existan razones relevantes para hacerlo, que se pued[e]n determinar libremente, pero que deben ser indicadas y justificadas" (cursivas añadidas). El artículo 196, párrafo segundo, fracción III, de la anterior Ley de Amparo, disponía explícitamente que un tribunal colegiado podía apartarse del precedente vinculante de otro, pero cumpliendo con la carga argumentativa de "expresa[r] las razones por las cuales considera[se] que no debe confirmarse el criterio sostenido en la referida tesis jurisprudencial". ${ }^{200}$ Este caso es un claro ejemplo

EX OFFICIO POR ÓRGANOS JURISDICCIONALES DE MENOR JERARQUÍA", Pleno, Gaceta del Semanario Judicial de la Federación, 10a. época, lib. 13, diciembre de 2014, t. I, tesis P./J. 64/2014 (10a.), p. 8; véase también "REVISIÓN EN AMPARO DIRECTO. ES INOPERANTE EL AGRAVIO TENDENTE A CUESTIONAR EL CRITERIO CONTENIDO EN LA JURISPRUDENCIA EMITIDA POR LA SUPREMA CORTE DE JUSTICIA DE LA NACIÓN, EN EL QUE SE SUSTENTÓ LA SENTENCIA RECURRIDA EN CUANTO AL TEMA DE CONSTITUCIONALIDAD”, Segunda Sala, Semanario Judicial de la Federación, 10a. época, lib. 67, junio de 2019, t. III, tesis 2a./J. 84/2019 (10a.), p. 1978. Cfr. Camarena González, op. cit., nota 104, pp. 339 y ss. (exponiendo cuatro posibles técnicas argumentativas [distinción, circunscripción, inaplicación y desaplicación] para vencer la fuerza vinculante del precedente, incluso en franca oposición a lo resuelto en dicha contradicción de tesis); y "JURISPRUDENCIA. LOS TRIBUNALES DE AMPARO DEBEN ANALIZAR LOS PLANTEAMIENTOS DIRIGIDOS A CUESTIONAR LA VALIDEZ CONSTITUCIONAL DE UNA DOCTRINA REFLEJADA EN AQUÉLLA”, Primera Sala, Gaceta del Semanario Judicial de la Federación, 10a. época, lib. 61, diciembre de 2018, t. I, tesis 1a. CCLVII/2018 (10a.), p. 344.

199 “JURISPRUDENCIA EMITIDA POR LA CORTE INTERAMERICANA DE DERECHOS HUMANOS. ES VINCULANTE PARA LOS JUECES MEXICANOS SIEMPRE QUE SEA MÁS FAVORABLE A LA PERSONA", Pleno, idem, 10a. época, lib. 5, abril de 2014, t. I, tesis P./J. 21/2014 (10a.), p. 204.

200 "JURISPRUDENCIA DE TRIBUNALES COLEGIADOS DE CIRCUITO. SU INOBSERVANCIA POR LAS AUTORIDADES QUE TIENEN OBLIGACIÓN DE ACATARLA CONFORME AL ARTÍCULO 193 DE LA LEY DE AMPARO, NO CONDUCE NECESARIAMENTE AL OTORGAMIENTO DE LA 
del "precedente horizontal" en sentido estricto; ${ }^{201}$ y a esta misma categoría de efecto vinculante se hallaría en México el "autoprecedente", como puede inferirse del artículo 228 de la Ley de Amparo vigente. ${ }^{202}$

4) Débilmente vinculante (weakly binding). En relación con este precedente "sólo hay una expectativa genérica de que el mismo sea seguido", creyéndose "oportuno" que así sea, "pero... no se producen consecuencias de relevancia si esto no pasa[ra]". Las tesis aisladas de la Suprema Corte de Justicia de la Nación contienen "fuertes orientaciones" para los demás tribunales, los cuales deben especial respeto a sus criterios dado su carácter de máximo tribunal, por lo que prima facie hay una expectativa de que sean seguidas; ${ }^{203}$ pero como no se impone explícitamente a éstos la carga de argumentar su decisión de apartarse de dichos precedentes (lo que no significa que metodológicamente carezcan de ella), su obligatoriedad no es tan fuerte como la de los señalados en el inciso anterior. ${ }^{204}$

5) (Meramente) persuasivo. A su respecto existe plena discrecionalidad sobre su seguimiento. En este supuesto se hallan los criterios aislados de los tribunales colegiados en relación con los juzgados

PROTECCIÓN CONSTITUCIONAL SOLICITADA", Semanario Judicial de la Federación y su Gaceta, 9a. época, t. XII, octubre de 2000, tesis XIV.2o.38 K, p. 1305.

201 Supra, nota 43.

202 “JURISPRUdencia DE LA CORTE", Pleno, Semanario Judicial de la Federación, 5a. época, t. XXIII, p. 652 (hay dos tesis con los mismos datos de identificación, registradas con los números 280993 y 280995 ; refiero ambas).

203 “Tesis aisladas de la Suprema CORTE DE Justicia de la NACión. El PRiNCIPIO DE IRRETROACTIVIDAD DE LA JURISPRUDENCIA, PREVISTO EN EL ARTÍCULO 217 , ÚlTimo PÁRRAFO, DE LA LEY DE AMPARO, LES ES APLICABLE”, Gaceta del Semanario Judicial de la Federación, lib. 28, marzo de 2016, t. II, tesis XVI.1o.A.24 K (10a.), p. 1790; y artículo cuarto, fracción I, inciso D), del Acuerdo General 5/2013 del Pleno de la Suprema Corte de Justicia de la Nación. Véanse también "SENTENCIAS DE AMPARO, FUERZA OBLIGATORIA DE LAS, AUNQUE NO SIENTEN JURISPRUDENCIA", Tercera Sala, Semanario Judicial de la Federación, 5a. época, t. LXIX, p. 4087; "SENTENCIAS DE AMPARO, FUERZAS OBLIGATORIAS DE LAS, AUNQUE NO SIENTEN JURISPRUDENCIA", Tercera Sala, ibidem, p. 4088; y "PRECEDENTES DE JURISPRUDENCIA", Tercera Sala, Informe de 1942, p. 45. Cfr. "JURISPRUDENCIA...", cit., nota 139; y "JURISPRUDENCIA DE LAS SAlAS DE LA SuPREMA CORTE DE JuSTICIA DE LA NACIÓN, OBLIGATORIEDAD Y APLICACIÓN PREFERENTE DE LA", idem, 9a. época, t. XIII, mayo de 2001, tesis XXII.1o.27 K, p. 1171.

204 Supra, nota 190.

Esta obra está bajo una Licencia Creative Commons Atribución-NoComercial-SinDerivar 4.0 Internacional, IIJ-UNAM. 
de distrito del circuito judicial que les corresponde. ${ }^{205}$ Se trata de un efecto vertical simple, a diferencia del referido en el inciso anterior, que podríamos calificar de "reforzado", por la máxima jerarquía de la Suprema Corte.

Especialmente respecto de tres últimas especies de la escala anterior, podría alegarse que la vinculatoriedad del precedente es cuestión de perspectiva: si dicha obligatoriedad pudiera ser vencida por su carácter prima facie, no sería tal, y el precedente en cuestión tampoco resultaría "vinculante" en modo alguno; o sea, como sostiene el punto de vista tradicional, afirmar que la vinculatoriedad de un precedente no sea definitiva sería otra manera de decir que el criterio judicial no es imperativo. Pero esta visión no acierta en la clave del problema: establecer a qué obliga especificamente cada precedente según sea provisional o absolutamente vinculante.

El efecto vinculante que prima facie tiene un precedente "persuasivo" - por hablar de la ínfima especie de la escala anterior- no compele a su aplicación incondicionada; pero sí exige respeto y consideración, y una cuidadosa si fuera uno "débilmente vinculante". ${ }^{206}$ El precedente de calidad "persuasiva" en sentido lato no impone que sea seguido de modo absoluto; en cambio, sí obliga a ser considerado en el razonamiento jurídico - especialmente cuando se invoca explícitamente-, y a que el operador jurídico "precis[e] si se acoge al criterio referido o extern[e] las razones por las cuales se separa de él". ${ }^{207} \mathrm{Y}$ un precedente de este género exige

205 Artículo 217, párrafos segundo y tercero, de la Ley de Amparo. Cfr. supra, nota 9. Véanse "TESIS AISLADAS. LAS EMITIDAS POR LA SUPREMA CORTE DE JUSTICIA DE LA NACIÓN TIENEN CARÁCTER ORIENTADOR, NO GENERAN DERECHOS NI SON SUSCEPTIBLES DEL EJERCICIO DE IRRETROACTIVIDAD", Segunda Sala, Gaceta del Semanario Judicial de la Federación, lib. 38, enero de 2017, t. I, tesis 2a./J. 195/2016 (10a.), p. 778; “TeSIS DE LA SUPREMA CORTE QUE NO INTEGRAN JURISPRUDENCIA. ES CORRECTO APOYARSE EN LOS CRITERIOS SUSTENTAdOS EN ELLAS", Apéndice al Semanario Judicial de la Federación 1917-2011, t. II, tesis 2509, p. 2957; u "AMPARO DIRECTO EN MATERIA ADMINISTRATIVA. PROCEDE EN TÉRMINOS DEL ARTÍCULO 170, FRACCIÓN II, DE LA LEY DE LA MATERIA, NO SÓLO CUANDO SE ADUZCAN CUESTIONES DE INCONSTITUCIONALIDAD, SINO TAMBIÉN DE LEGALIDAD, CONFORME AL PRINCIPIO PRO PERSONA", Gaceta del Semanario Judicial de la Federación, 10a. época, lib. 18, mayo de 2015, tesis IV.2o.A.80 K (10a.), p. 2103.

206 Supra, nota 195.

207 “TESIS DE JURISPRUDENCIA, AISLADAS O PRECEDENTES INVOCADOS EN LA DEMANDA DE AMPARO. CORRESPONDE AL ÓRGANO JURISDICCIONAL PRONUNCIARSE SOBRE SU APLICABILIDAD AL CASO CONCRETO, AL MARGEN DE QUE EL QUEJOSO EXPRESE O NO RA- 
cumplir esta carga con una mayor intensidad de tratarse de uno sentado por un órgano judicial de máxima jerarquía, como las tesis aisladas de la Suprema Corte, y requeriría "argumentos cualitativamente superiores" para ser soslayado.

Los precedentes tradicionalmente "no vinculantes" poseen en realidad una "vinculatoriedad dialéctica", que si bien no imposibilita apartarse de su sentido, obliga a que ello no se haga arbitrariamente sino con base en "argumentos objetivos, razonables y públicamente expuestos" con diferentes grados de pormenorización. Esto, en aras de los principios constitucionales a que sirve esta figura, y muy en especial a la seguridad jurídica y su prohibición de arbitrariedad. ${ }^{208}$

De lo anterior podemos concluir que: 1) todo precedente tiene un efecto vinculante prima facie, que se despliega al menos en el sentido dialéctico apuntado imponiendo una carga argumentativa, y su obligatoriedad en términos sustantivos absolutos tiene lugar sólo de modo excepcional; 2) hay distintos grados de efecto vinculante de acuerdo con los estratos en que esté organizado el sistema judicial y otros elementos que determinada el sistema jurídico, y 3) fuera de este casos excepcional, en aras de la seguridad jurídica - en sus vertientes de predictibilidad e interdicción de la arbitrariedady de los demás valores adscritos al stare decisis, para apartarse del sentido de un precedente siempre se requiere una argumentación cualitativamente proporcional al vigor de su efecto dialécticamente vinculante.

\section{El criterio judicial "ejemplar"}

Una figura afín al precedente es el - llamémosle así, pero indebidamente por lo que luego diré- "precedente ejemplar" o simplemente "ejem-

ZONAMIENTOS QUE JUSTIFIQUEN SU APLICACIÓN", Segunda Sala, Gaceta del Semanario Judicial de la Federación, 10a. época, lib. 53, abril de 2018, t. I, tesis 2a./J. 32/2018 (10a.), p. 847. Véase también "TESIS AISLADA O DE JURISPRUDENCIA INVOCADA EN LA DEMANDA DE AMPARO. CORRESPONDE AL ÓRGANO JURISDICCIONAL PRONUNCIARSE EN TORNO A SU APLICABILIDAD O INAPLICABILIDAD AL CASO CONCRETO, INDEPENDIENTEMENTE DE QUE LA QUEJOSA ESGRIMA O NO ALGÚN RAZONAMIENTO AL RESPECTO”, Segunda Sala, Apéndice al Semanario Judicial de la Federación 1917-2011, t. II, tesis 1731, p. 1967.

208 El concepto de "vinculatoriedad dialéctica" fue acuñado por la Suprema Corte de Justicia de la Nación en relación con las iniciativas de leyes de ingresos municipales y su consideración por las legislaturas estatales. Por todos véase Pleno, controversia constitucional 15/2006, sentencia del 26 de junio de 2006, Diario Oficial de la Federación, 9 de febrero de 2007, 1a. sección, con. VI, pp. 11-14.

Esta obra está bajo una Licencia Creative Commons Atribución-NoComercial-SinDerivar 4.0 Internacional, IIJ-UNAM. 
plo". Se trata de un criterio judicial con efectos meramente ilustrativos, que en ocasiones se le confunde con el precedente persuasivo referido en el nivel ínfimo de la escala recién expuesta.

Para construir argumentos de apoyo a una decisión pueden aducirse criterios de tribunales análogos al que controla al juzgador actuante, de tribunales extranjeros o internacionales a cuya jurisdicción nuestro país no esté sometido. ${ }^{209}$ Pero la eventual aplicación de estos criterios no se da por su calidad de "precedentes" sino como "ejemplos", con el propósito de "mostrar un posible significado [con mayor o menor autoridad] de una regla jurídica, pero sin la pretensión de derivar indicaciones influyentes en la decisión del caso sucesivo". ${ }^{210}$ La diferencia entre el "precedente" y el "ejemplo" consiste en que el último carece de autoridad formal, pero a juicio del operador jurídico la tiene con carácter material.

La ratio decidendi sólo tiene calidad de "precedente" en sentido estricto, y tiene autoridad (formal) para influir sobre la decisión del caso posterior, ${ }^{211}$ porque el juez que resuelve éste se halla en alguna medida obligado a seguir su sentido para decidir el caso "correctamente", como probablemente lo haría el tribunal que lo hubiera de resolver definitivamente. Ninguno de los tipos de criterio judicial "ejemplar" mencionados en el párrafo anterior tiene normativamente esta aptitud; sin embargo, atendiendo la calidad de sus razonamientos y la autoridad material con que los reviste, cualquier tribunal podría tomarlos como "ejemplo" y asumir su criterio. Para distinguirlas conceptualmente, más que "persuasivas", las rationes de un criterio judicial ejemplar habrían de concebirse como absolutamente "optativas", ${ }^{212}$ siendo tomadas como modelo por el juzgador actuante al atribuirles una calidad superior que busca emular, es decir,

209 Para profundizar en las últimas dos especies mencionadas, especialmente en torno al problema de la autoridad material de tribunales referentes, véase Ponthoreau, MarieClaire, "La circulación judicial del «argumento de derecho comparado». Algunos problemas teóricos y técnicos a propósito del recurso a precedentes extranjeros por el juez constitucional", trad. de Rubén Sánchez Gil, Revista Iberoamericana de Derecho Procesal Constitucional, México, núm. 14, julio-diciembre de 2010, pp. 225-246.

210 Taruffo, op. cit., nota 40, pp. 197, 198 y 205. Véanse también MacCormick y Summers (eds.), op. cit., nota 5, p. 519.

211 Taruffo, op. cit., nota 40, pp. 198 y 204. Cfr. Gómora Juárez, op. cit., nota 10, pp. 112-116.

212 Ibidem, p. 113 (n. 207) (abordando el recurso comparativo a sentencias de tribunales extranjeros). 
alguna clase de autoridad en sentido material. Los ejemplos "pueden ser respetados por su razonamiento y seguidos en nombre de la uniformidad y de la consideración (comity)", no porque de alguna manera el tribunal que las invoca esté sujeto a ellos. ${ }^{213}$

Una muestra del uso de un "criterio judicial ejemplar" sería el caso de un juez civil de primera instancia que tomara como "parámetro de interpretación" 214 un criterio establecido por el Tribunal Electoral del Poder Judicial de la Federación, ${ }^{215}$ que de ninguna manera vincula su labor. ${ }^{216}$ De acuerdo con los párrafos segundo y tercero del artículo 217 de la vigente Ley de Amparo, otro ejemplo lo daría un juez de distrito que apoyara su resolución sobre la jurisprudencia de un tribunal colegiado correspondiente a un circuito al cual no pertenece, y que por lo mismo no estaría obligado a seguir. ${ }^{217}$

Ningún impedimento existe para que, en las hipótesis anteriores, el juzgador actuante haga suyas las razones de un tribunal cuyo criterio no le obliga en absoluto. En todo caso, podría criticarse la pertinencia de la aplicación de dicho razonamiento, pero de ningún modo sería reprochable la expresión de su origen. Por el contrario, ésta más bien resulta plausible, por contribuir a la transparencia y a la verificabilidad de la decisión judicial.

Una situación muy peculiar puede producirse cuando el tribunal competente para establecer un precedente desaparece o se le priva de alguna de sus atribuciones. Cuando hipotéticamente se ha planteado esta cuestión, ha habido respuestas muy diversas y extremas; pero la solución estaría ubicada en un término medio. En estas condiciones, la mejor opción parece ser

213 Garner et al., op. cit., nota 8, p. 34.

214 Véase "SUSPENSIÓN DEL ACTO IMPUGNADO EN EL JUICIO CONTENCIOSO ADMINISTRATIVO. No LE ES APLICABLE DIRECTA NI SUPLETORIAMENTE LA LEY DE AMPARO", Segunda Sala, Gaceta del Semanario Judicial de la Federación, lib. 43, junio de 2017, t. II, tesis 2a. LXIX/2017 (10a.), p. 1450.

215 Por ejemplo: "Promociones. CUANDo ES EVIDENTE QUE SU LiTERALIDAD SE OPONE A LA CLARA INTENCIÓN DEL SUSCRIPTOR, DEBE PREVALECER ÉSTA”, Sala Superior, Compilación Oficial de Jurisprudencia y Tesis Relevantes 1997-2005, tesis S3ELJ 66/2002, p. 249.

216 Véase el artículo 233 de la Ley Orgánica del Poder Judicial de la Federación.

217 “TESIS DE LOS TRIBUNALES COLEGIADOS QUE NO CONSTITUYEN JURISPRUDENCIA PUEDEN SER APLICADAS POR LOS JUECES DE DISTRITO AUN CUANDO NO PERTENEZCAN AL CIRCUITO DEL TRIBUNAL COLEGIADO QUE LAS SUSTENTÓ", Semanario Judicial de la Federación, 8a. época, t. XV-I, febrero de 1995, tesis X.1o. 34 K, p. 278. 
que los criterios del tribunal extinto carecerían de autoridad formal para imponerse, y los tribunales que antes habrían de seguirlo se encuentran libres de todo vínculo a su respecto, salvo por la necesidad de preservar la seguridad jurídica lato sensu, que los impelería a respetar, y a no soslayar abierta y arbitrariamente dichos criterios, en atención a la autoridad material que les otorgaría el conocimiento experto atribuible al tribunal que los emitió. Sin embargo, esta vinculación no sería inflexible, sino en realidad muy débil, y salvo por imponer una básica carga de argumentación no impediría alejarse del criterio correspondiente. En tal virtud, porque seguir dicho criterio no tendería a encaminar la solución del caso actual a la respuesta que con mayor o menor probabilidad le daría el tribunal que en la actualidad tendría que resolverlo en última instancia, no se estaría ante un precedente propiamente dicho, sino frente a un "ejemplo", uno excepcionalmente muy fuerte, pero al cabo un criterio judicial de seguimiento optativo. $^{218}$

\section{REFLEXIONES FINALES}

Las consideraciones anteriores ponen de manifiesto que en el juego argumentativo jurisprudencial hay más "matices y complicaciones" de los que comúnmente se piensa. ${ }^{219}$ La aplicación de los precedentes judiciales, o de la "jurisprudencia" — como se prefiera—, implica mucho más que la fidelidad irreflexiva a los criterios establecidos por los tribunales. Y la adecuada operación jurisprudencial en México debe atender las particularidades de esta fuente jurídica.

Los dos problemas que expuse —el empleo de tesis, que se traduce en la vinculación del precedente judicial con la configuración fáctica del caso en el que se estableció, y los diferentes grados de efecto vinculante que podría tener-constituyen a mi parecer los más importantes que afrontamos en México en relación con el derecho de elaboración judicial, pero de ninguna manera son los únicos. En distintos aspectos, la Ley de Amparo de

218 Caminker, op . cit., nota 44, pp. 867-869. Cfr. "JURISPRUDENCIA DE LA SUPREMA CORTE. LOS TRIBUNALES COLEGIADOS ESTÁN FACULTADOS PARA MODIFICAR LA ESTABLECIDA CON ANTERIORIDAD AL 15 DE ENERO DE 1988, CUANDO VERSE SOBRE CUESTIONES QUE SEAN DE SU COMPETENCIA EXCLUSIVA", Pleno, Apéndice al Semanario Judicial de la Federación 1917-2011, t. II, tesis 1721, p. 1955.

219 Supra, nota 8.

Esta obra está bajo una Licencia Creative Commons

Atribución-NoComercial-SinDerivar 4.0 Internacional, IIJ-UNAM. 
2013 , los nuevos acuerdos generales plenarios 16/2019 y 17/2019, y otros elementos normativos, han pretendido mejorar el sistema jurisprudencial de nuestro país, pero a su vez suscitan otras dificultades: la cuestión de la irretroactividad de la jurisprudencia ya tiene una importancia renovada, y aún está por definirse con claridad la situación de precedentes que no se hayan divulgado mediante el Semanario, pero sí por otros medios, como el Diario Oficial de la Federación, que permitirían un "grado de certeza aceptable" sobre su existencia. ${ }^{220}$ Asimismo, muchos de los aspectos aquí tratados harán surgir cuestionamientos, objeciones y otra clase de problemas, en especial sobre sus implicaciones (dogmáticas y prácticas) para el ordenamiento mexicano.

De cualquier manera, en México necesitamos repensar la jurisprudencia, partiendo de una sana duda metódica y volver a elaborar en serio nuestros conceptos sobre ella — si alguna vez lo hicimos más allá de lo estrictamente elemental-, comenzando con el mismo fundamento constitucional de esta figura en nuestro sistema jurídico, y reconocer los importantes valores jurídicos a que sirve. Es necesario que los juristas mexicanos conozcamos mejor la naturaleza del precedente judicial; no se pueden resolver correctamente las dificultades que nos plantea si continuamos ignorando el trasfondo sobre el cual tienen lugar, y las implicaciones que pueden tener las distintas soluciones que se les pretenda dar. Indudablemente, adentrarnos en los pormenores del precedente judicial va a presentar dificultades para nosotros, por tratarse de una figura no sólo ajena a nuestra tradición jurídica, sino que históricamente ésta ha menospreciado y aun rechazado.

Adentrarnos en las peculiaridades del derecho jurisprudencial va a exigirnos, primeramente, un cambio de cultura y de mentalidad sobre la labor de los jueces y de las implicaciones de sus decisiones para la construcción del ordenamiento jurídico. Asimismo, nos requerirá un gran esfuerzo y una labor más ardua, porque implica mejorar la calidad de nuestra argumentación.

Sin embargo, creo que antes de arredrarnos y renunciar a un empleo más preciso de los precedentes judiciales, estas dificultades deberían inspirarnos a conocer su naturaleza para controlar más nuestro derecho jurisprudencial, con el propósito de mejorar la calidad de la impartición de

220 Supra, nota 147. 
justicia en nuestro país, especialmente en el ámbito constitucional, cuyo contenido — por las características de sus disposiciones - en buena medida configura la interpretación de los tribunales. Este último fin me parece justificación suficiente para que en México comencemos a estudiar la jurisprudencia con seriedad y precisión técnica.

Fecha de recepción: 4 de septiembre de 2019.

Fecha de aceptación: 6 de enero de 2020.

Esta obra está bajo una Licencia Creative Commons

Atribución-NoComercial-SinDerivar 4.0 Internacional, IIJ-UNAM. 